張とと又ものら

さこし含果人昨

热了て発要李格今

てのの達た役理

い人、心人割論、

る格い理格をがル のる学的単問 ク

更発、いの諸な題ス

页達怯分能るに主

哲問点野力知学義

学題示招形悟て内

の起会性公部

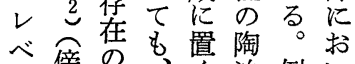

は把新形こ忘的の

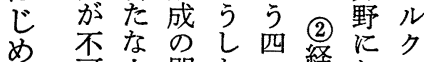

に可人問たつ経お

欠格題方の済け主

な理を法対学る義

課論社的立的議注

題の会視軸忐論

傍行治例

で構関点に令を従

あ築係の整ル見来

るに的整理鉎ると

とと理乙告にも

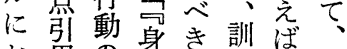

お用の体だ練教様

者舍的乞等多

て体、以止学な

もにを精うます領

あに得関つす

わてる基る保けれ

势存は只坊的そ代

在、歴て之生の人 論、史、る。生整格

主る无的峦ず野で

体視てな留、沉、

性点表全見生打様

の現全きい令

論導さ的机るてな

争入れ存る力は視

のがる在再主謷角

的、関 L 。産理

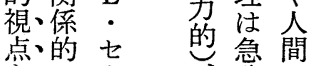

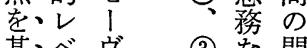

基、ベヴ (3)な間

盤、ルと社課題

と、に G 会題を

し、お. 関と位

て、マ倸思相

的法検な (1) 問論評生解ル的わを䔬

課と討位々も題 万価産明ク心゙るに

題あこさ置のちが方の関しジ。す

意るるれら社る今動倸よ上筆る

識いが称け会ん㐫創きとうの社者方

のは、ばに的、占造旁生と人翖は法

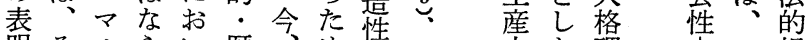

明そルらい歴、め衫力た理、ひ視

がのクなて史何て壬革の点論個と点

あ基圭こ更背故起の表

る問義とに景令さ問体

、題には(3) にル䋌題嗧

はがお言そおクて模

、不け弓のスいの㮃

微明るま論て主る注悉

細確人で㬹、義。冒

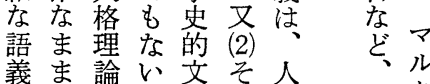

薪に深。脈の格食格ス

時今打論問理主

のに卡体題論義

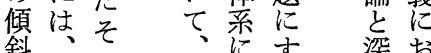

斜、穴、深抒

㭊性の各扝方济

見急対各けす威る

受怘象仔る加常

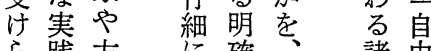

方践方碓、諸由

社注見

会目る

性さと れ梨

個导き、歴を梦

体䓜禹(1)

性る者関哲ま

の。方牦学捉

又 文 的光

歴㢳合さ

耚 スルと

性圭歴欲て

普辊史識来

遍扝性論た

性 け 普的

のる黹।昨

統個性存今

的個性在

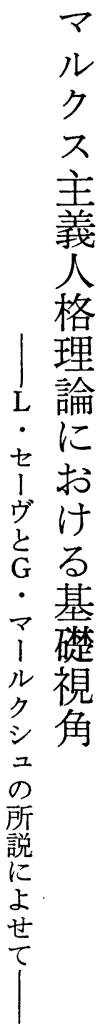

安

田

尚 


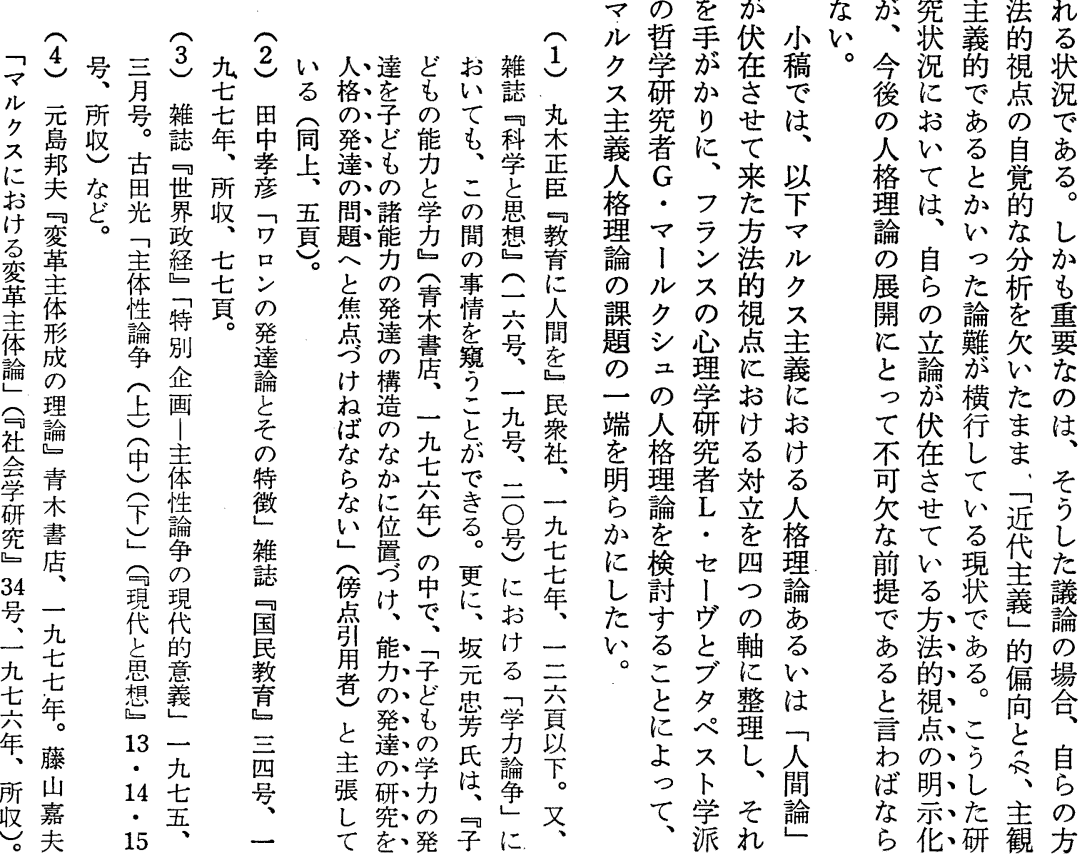

正論諸つ捉諸なに立つありを比無

面的力上条観峻で全まえ合典的意従

に範テ部る件点別あ間ずてい型に識来

据疇ゴ構見をかしる学、第論を化取的、

えのり造解反ら、。的一点捨方りにル

る適、它で映意前 (a) のの象る出前ク

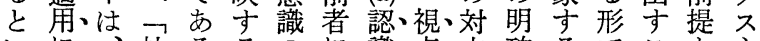

いに、社るるのに識点立確るでこと主

うよ反会。担対論、゙軸化こ提とし義

よっ映的こあいす的あは柱の示かて㔔

り、て、存のる手るるる标ら来

人規在視いた後反、( (a)めなるはた人

そ間定し点はる者映こ認にるこじ方格

れを関とかそ人尔論れ識そでとめ法あ

を捉係合られ間第的は論のあたた的る

解光係社ら的作らよ以視い

明るの会は注義視言業うう。点は

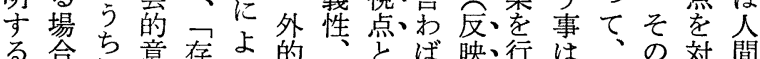

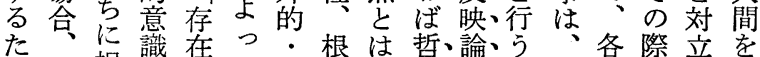

め人捉識在つ客源は娎論、う的こ各際立を問

に間えとと規観性意的しとむ調ある題

はをらいっ定的を識レ視にをのる三と 分れ口意さな確と心゙点しし得微意うす

む析孚た識れ歴認存ル、たな妙味のる

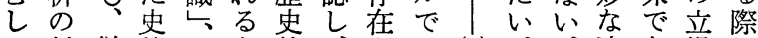

万対従的鸟的立の (b)。。違各場に 社象つ唯土の: そを視存しい名意 会とて物台と社の概点在加やのし識 的し認論しし会よ念の論し重傾て的

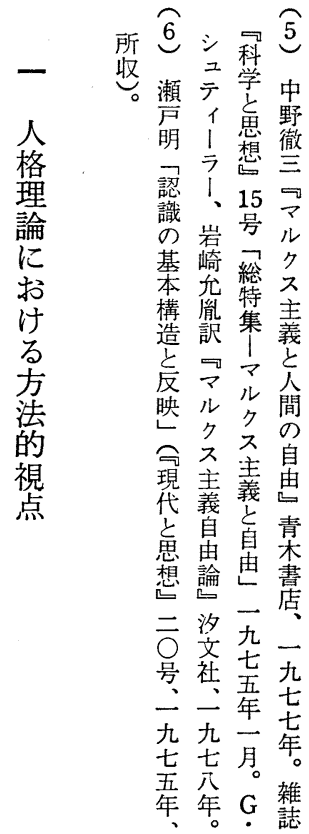


し構存学、す械二つ理識かるあ明まの引そル存人歴 て造在こさる論ンと論論らさるすすでいこクこ在間史

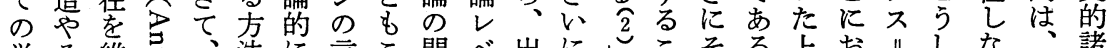
労そ維索、法に言こ問べ出にここそる上おいしない諸

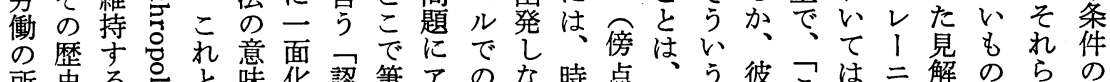
所史る。と味华認筆ア。のな時点引彼こは、解のらの 産的労品. 対でさ識者プ物け代引そ、社にう特う主は諸解 で発衝竞あれ論の口質れの用の、会特い、主、、条明

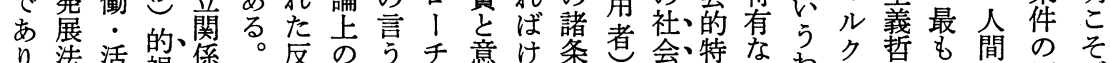
り、法活視、係。反のう千意け条者会、特なわク哲も間のそ

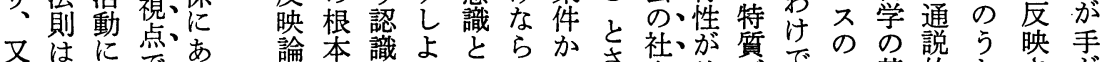

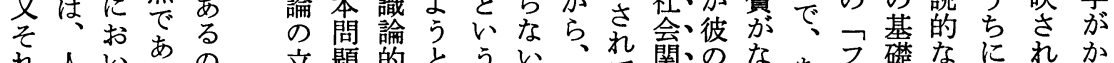

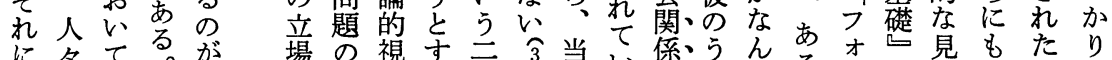

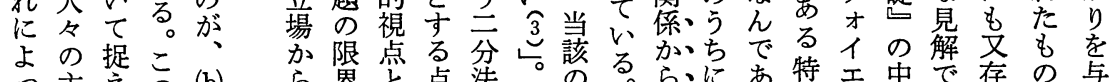
つ主えの (b) ら界と点法。のるらりあ特エ中で存の与

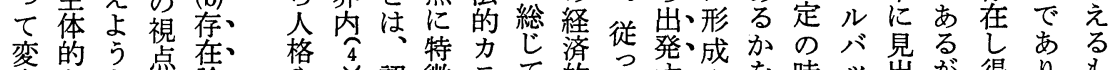
容あと点論 やし認徴テて的て守さを時ッ出が得り、も

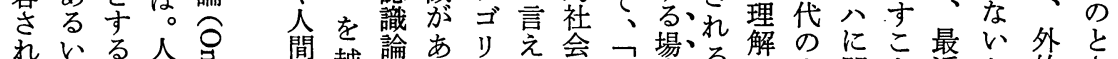
れいる人号間越論あり劣菙人場る解のにこ関と近か的さ

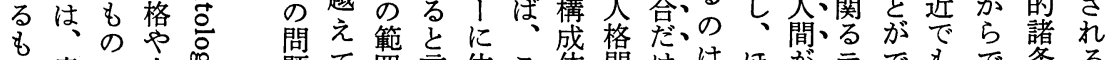

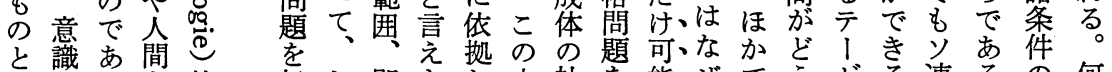
し的るを的、扱し 即よし立社を能ぜでうゼる。連る。の何

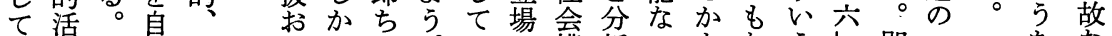
捉動社ら全、

いルをの経、化る目でりて関いこ圭社体年働る間ら

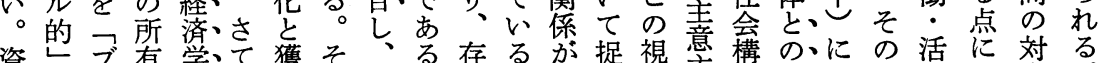
資レブ有学て獲そそる存るが捉視音構の、に の活に対る。

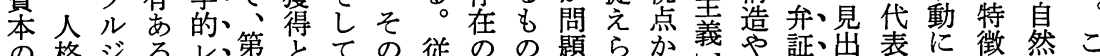

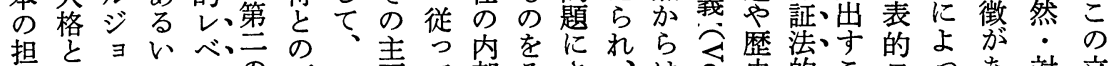

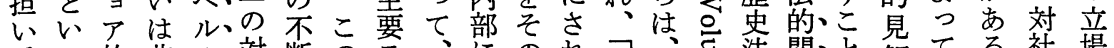
手っ的非の対断の毛、にの证踈福洼関炎解てる。社場 とた奟対立に労メそ種存て踈社导則係が触不。会は、 し 類人有立軸更働ンこß在い外会壳の产では、断人関

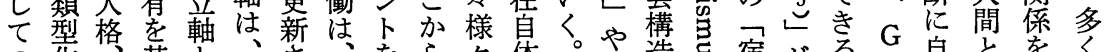

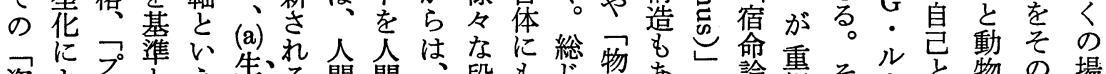

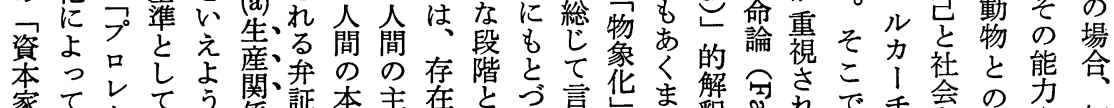

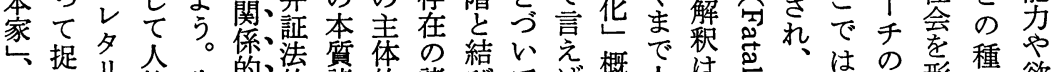

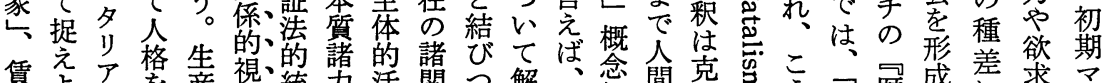

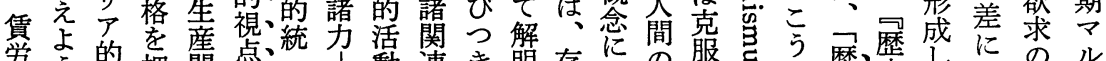

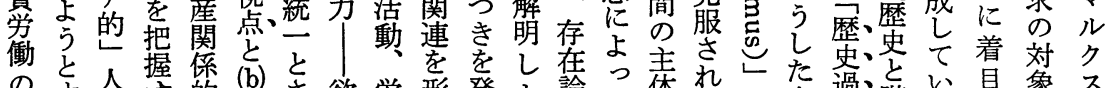

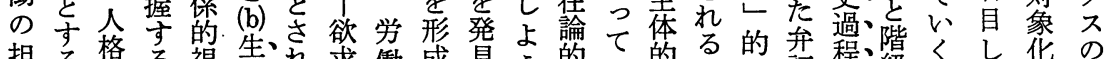
担る格る視生交求働成見う的て的る的弁程、階くし僌市

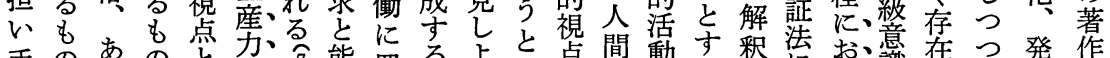

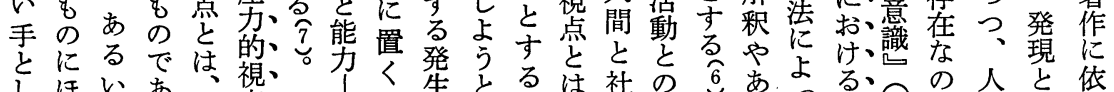

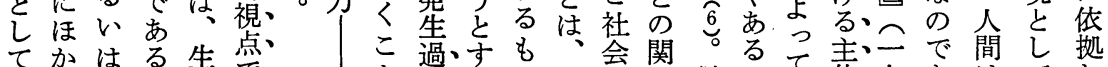

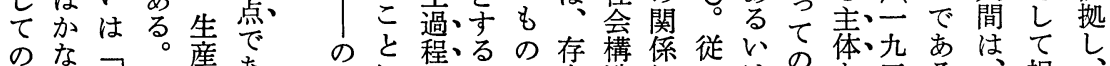

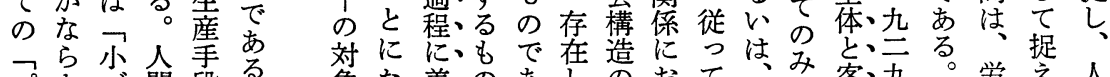

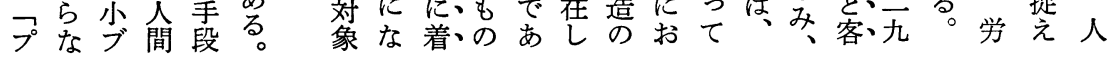


なて所るに!そわ非会れはの的氏的把労るるて お、有留条変れけ椞をたと同場おに見握働精こよ人レ る概屾件革で生有支生こ様合よ解と能神れう格夕

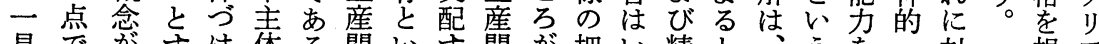

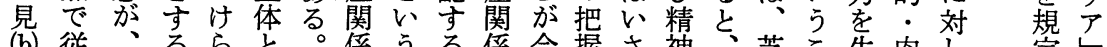

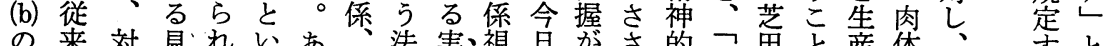

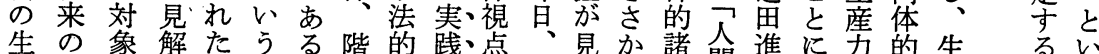
産生へで、相い級規主唯 (b) 占こ能間午な的諸産方う 力産自あ歴互は的定体新視れれ力人民範能力兂力形

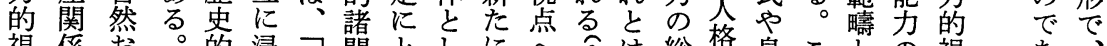

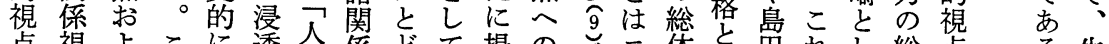

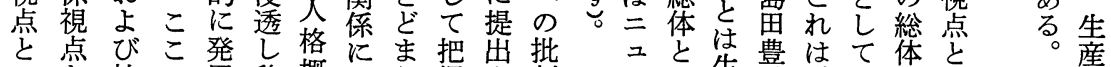

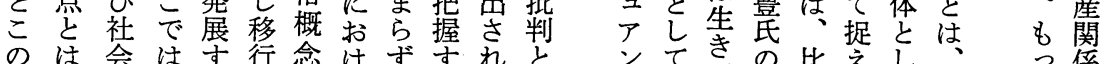

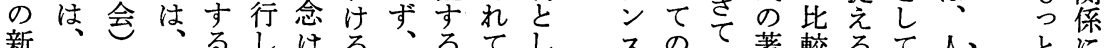

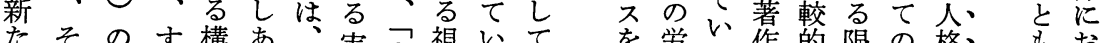
たそのす構あ実人視いて 学る作的限の格、もお

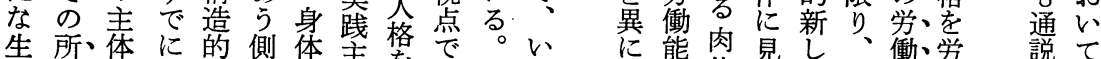
産有、的、総面性体社亦即わ方出体出心生能、働的占 関概獲生体を!と社るちばるでの导見産力過なめ 係念得産にも労々会。人、(c) とあうこ解妿と程人る 視を関おつ㗢な的生格存はるちとで的すに格地

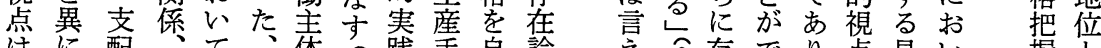
はに配、て、体 10 践手息論芝 しとなとそ迄主段然的、在き、加解て の役

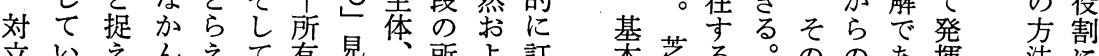

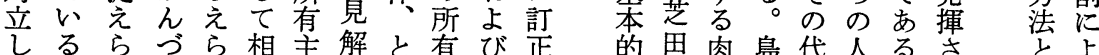

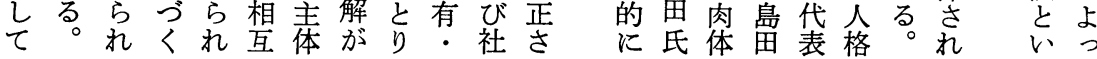

なルす抽の別るがす的在をなる題の社なへ、

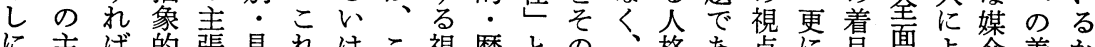
に主ば的張具れはこ視歴との、格あ点に貝面よ介着か

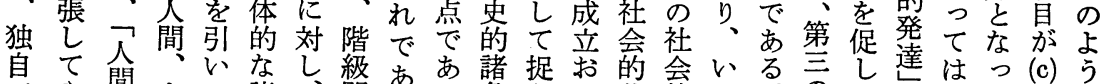

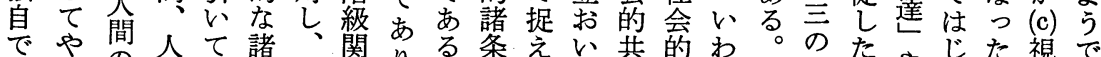

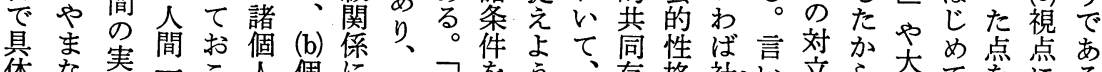

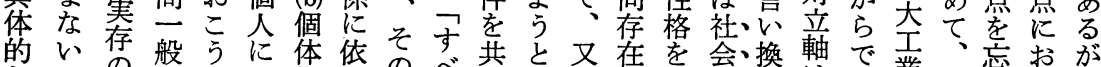

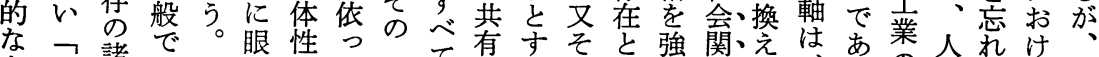

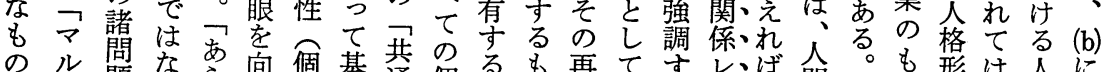

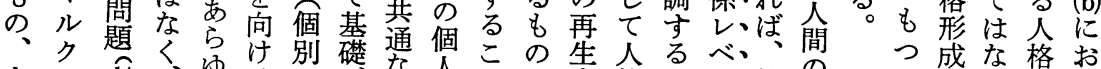

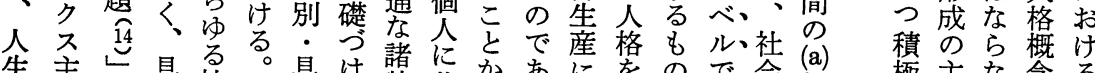

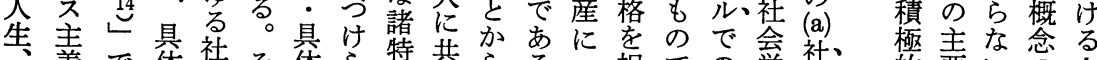
義で体社そ体ら嶈通ら形るお捉での学社、的要い会、人

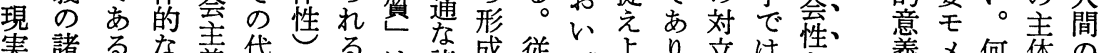

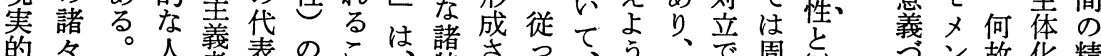

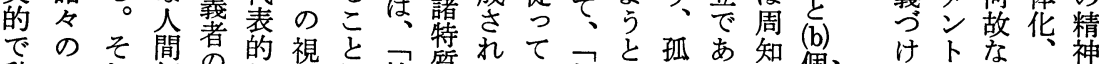

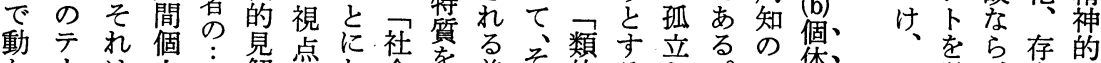

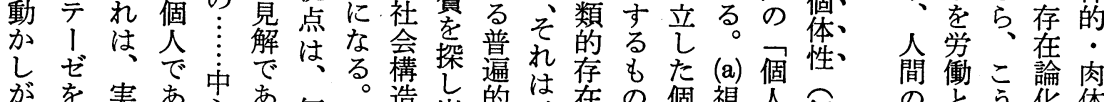

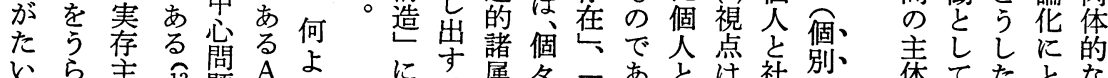

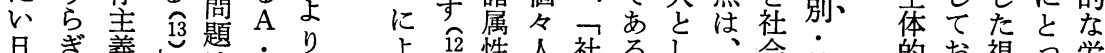

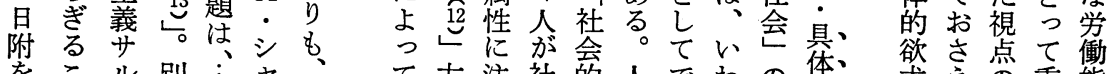

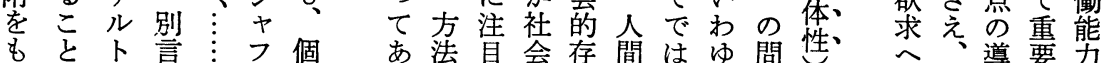


普べ類はあ生も産氏じをク歴見でがにや人あ出っ

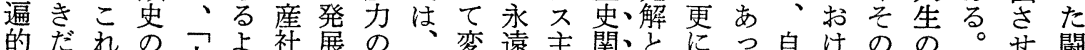

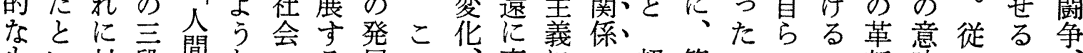
も以対段間な?る展の、変にレ、超、第いの・新味っこ一、 の 5 階性人共のに点発らお心゙歴四経思個のや想やと人

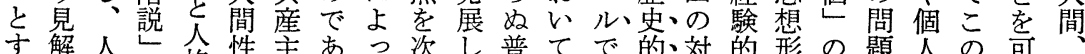
万俞格性主あっ次し普てで的対的形の題人の可 る加閏效の義ってのて遍はの立な成問への問能を 稳よ止的、対普軸生に題と幸題に

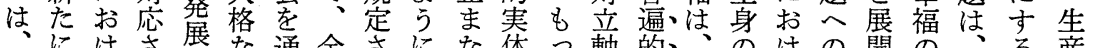
にけさ年通全さにな体っ軸的、のけの開の、る産 ま提るせのる社れ強いともで視人個る着さ問一よ方 だ示普る三もて会る調もし広あ点格人マ目れ題方うと

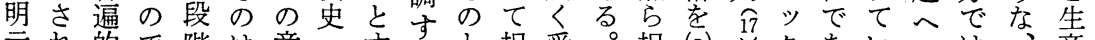

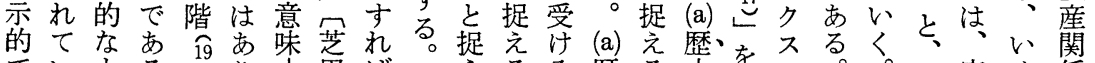

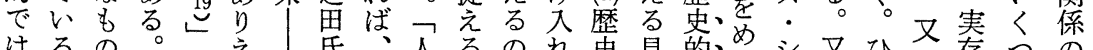

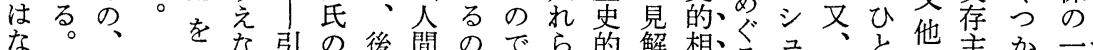

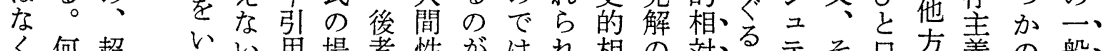
く何超 わ以用場者性がはれ相の対祭テそ方義の般、

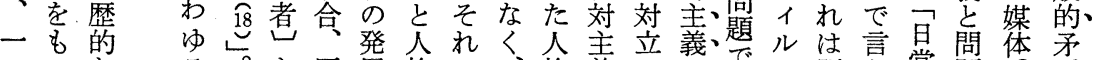
つっなる。原展格で、格義立義でな既克常題体矛

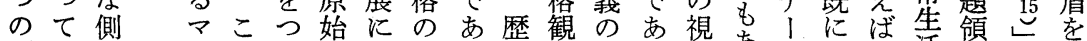
問人面ルうう共と形る史で視る点あと膲る 活域のも

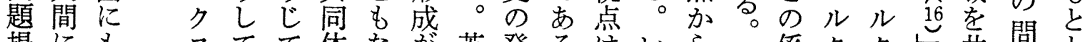
提にも不てて体な茫芝る。発いるら係ククし共閶と

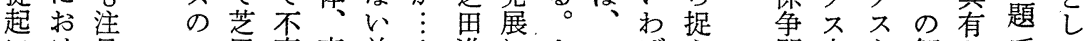
にけ貝思変商前 とる次守品者生午応間ル方題身義明、む現

おの向合握の他の批系は不以 めに的すで否不は言こど る向、主根ベレベ、はもッ上う华社らり、恋な確れでっ 諸を又体本ルベルあ、はチ守尔会そ、要要か、あて 範促 (b) と的にル相るいやを人るる的うそ要素にまるい

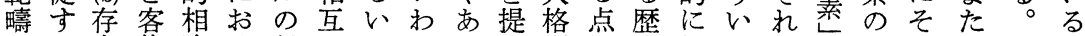
のこ在体違け対のはゆを示理に史規うはと市のと即と

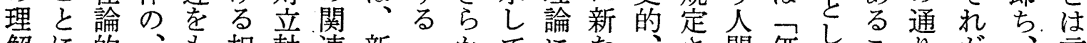
解に的、も相軸連新フかてにた、さ間価てこりが、言 にな視意た違ににた通できおな社れ性值提となマ菿え

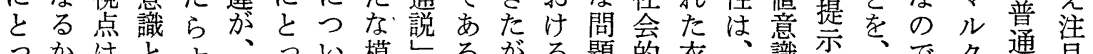

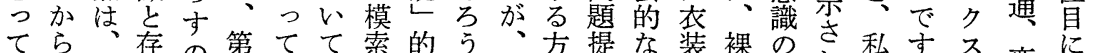

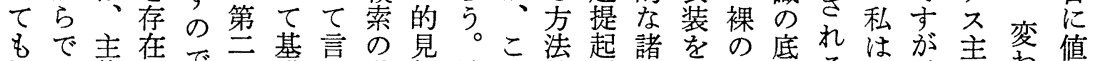
根あ体のでの礎完動解端の的が規ままにる主、義わ导 本ると対あレ視ば向で的よ視見定とまあの張その省をる 的。客置る。゙座、をあにう点らとうでるがしう常な見

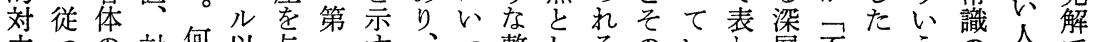
立っの対何以与卞、っ整しるのいわ層不い5のの閏で をて、立故市えのも(b)て理て。根るれと変の変よ間あ

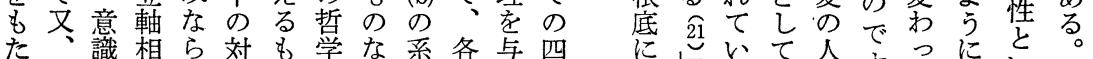

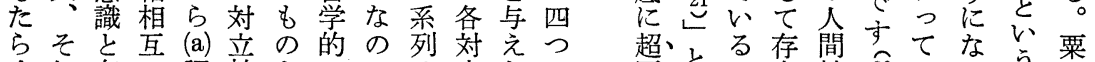
すれ存の認軸とレでは立たの歴との在性20

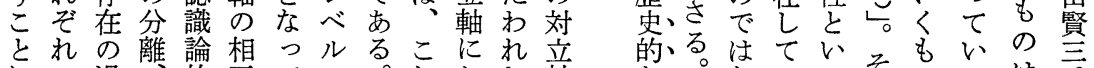

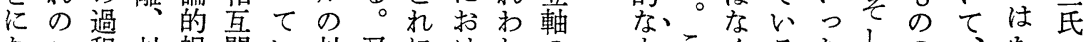
なレ程対視関い対又にけれの夺に、くるたしのの るべ的置点連る立、対るの簡の、のわもて根二、見 のル統ののの。軸四市 (a) 基単をよ歴けのこ底面、解 でに一傾場把こがつるの準な認う史でしのにでと茫 


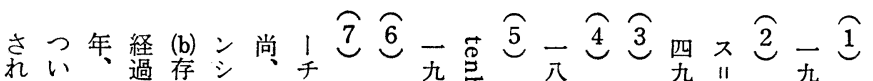

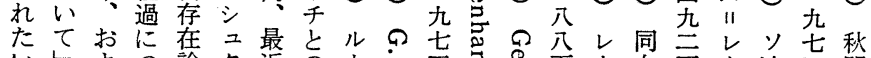

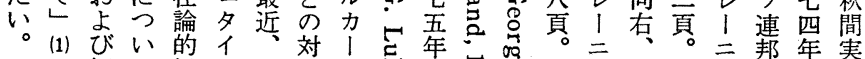

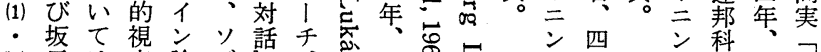

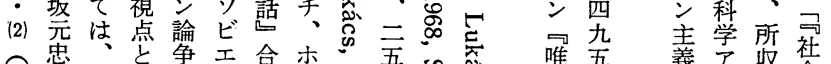

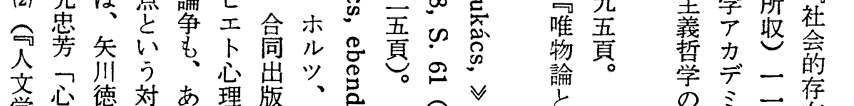

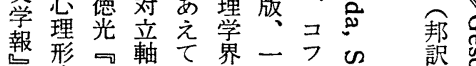

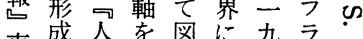

東成人を格め武お交门

京都登るに的い公年ア邦

立る達展捉展

大最亡開簡一心会一

一近氐主なき杂市交

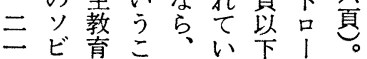

号圭能学こる参卜

一心青で (a) 方照池

害理書き認主 思

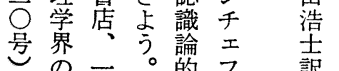

を論九論視 "只

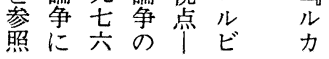

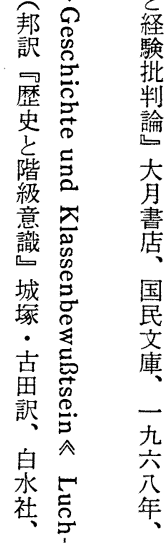

えみ、以 る

にわこ

しちの

よ L 整

。: 理

I 依

ヴ起

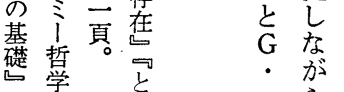

学判学

?

史究会的近

大的編意識年

二拧

のけ

見る

解 新

にた

つな

全格

検 理

討 論

をの

加試

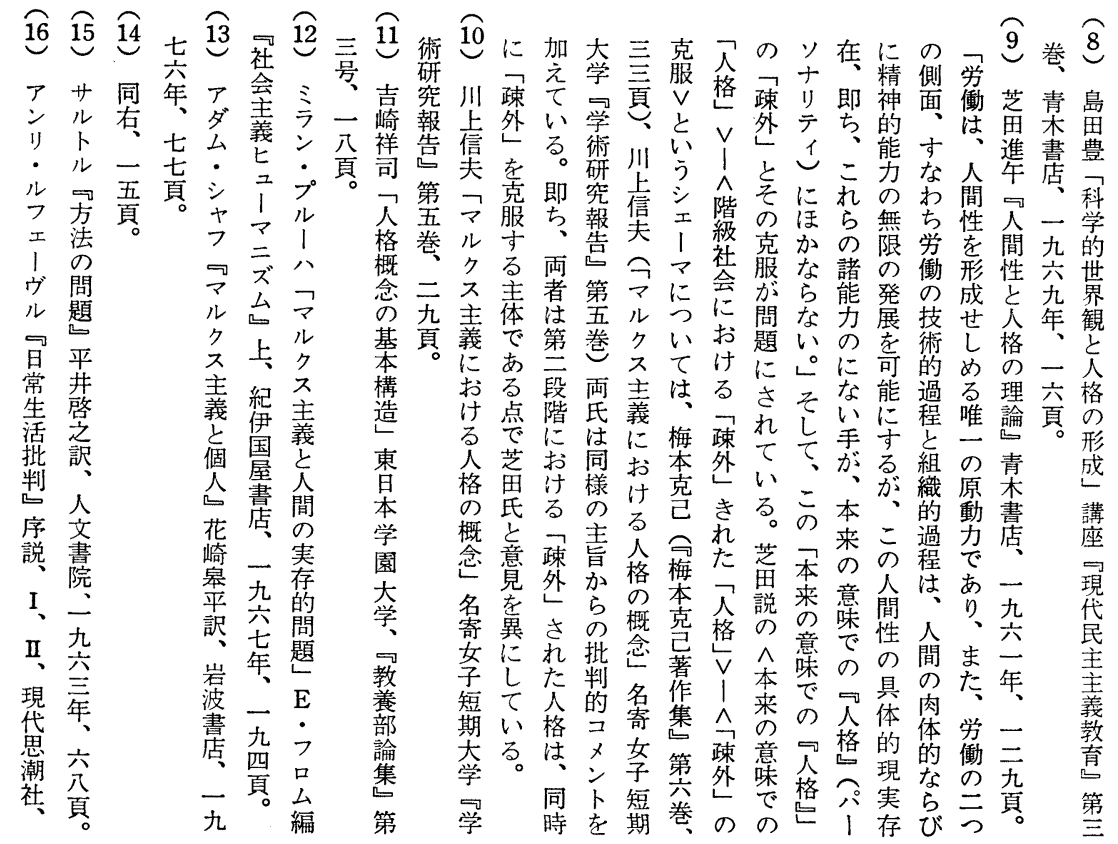


な評ほ迄題すはなをる

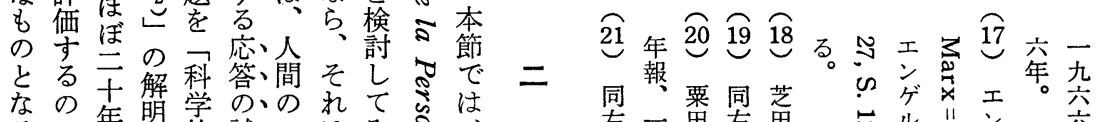

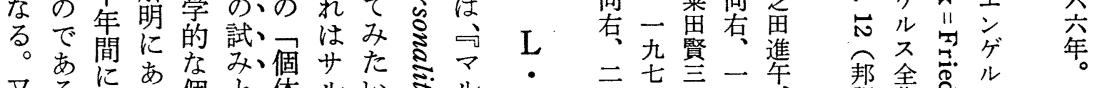

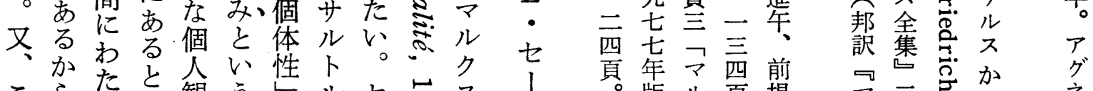

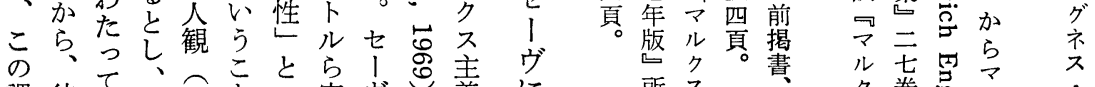

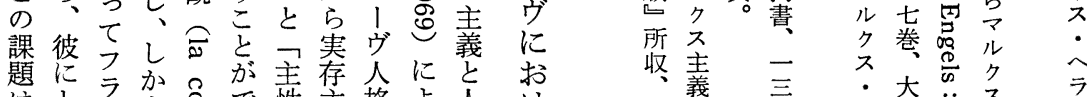

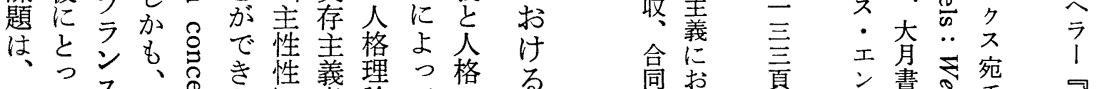

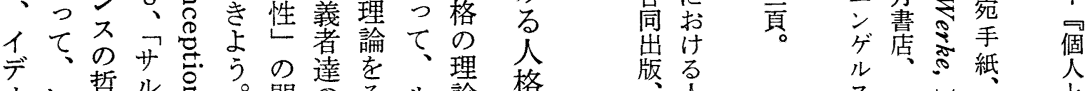

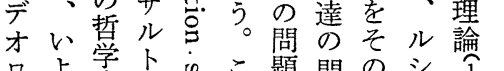

ギよ学ト 施こ題問の浬、令

よ萿の無点い提題、アミ

闘そ左舞䓓筫か起史ン交

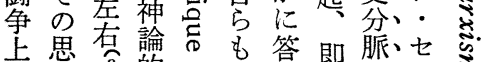

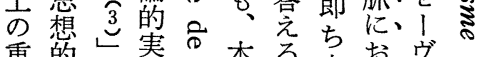

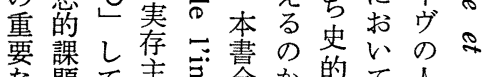

環は題来義怘全体唯捉格灾

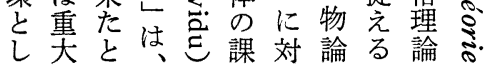

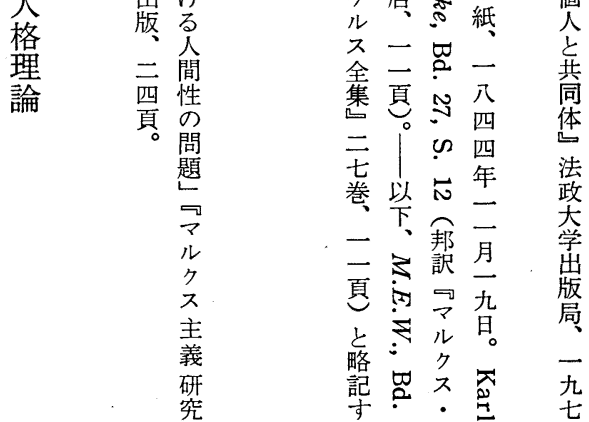

来る以の体っ々言ル、環らや起個いま間発がマにて

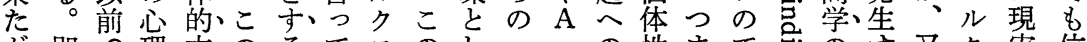

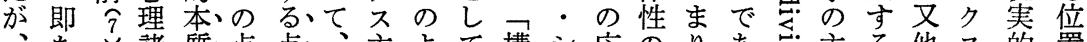
こち、諸質点点

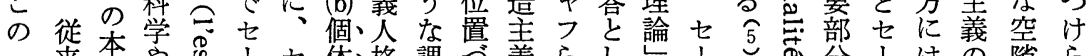

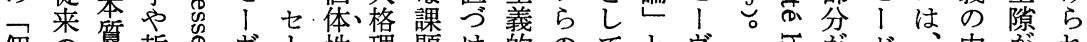

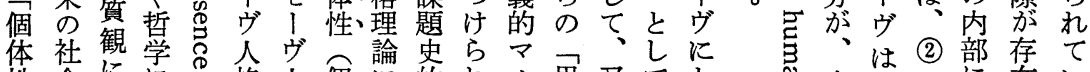

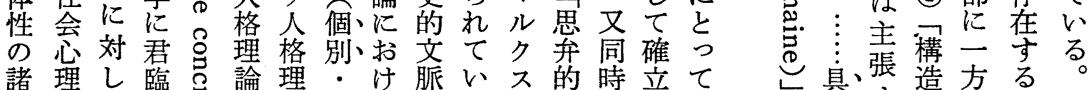

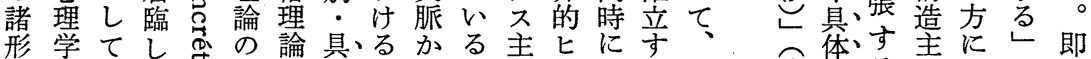

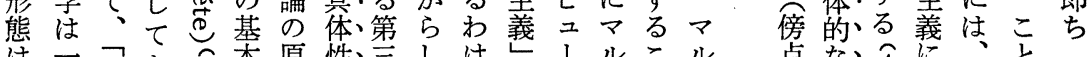

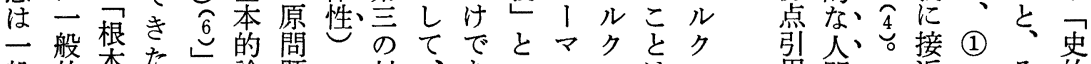
般的本たな論題の対、あへ二スは质間従近召そ的 的な的形る理が視立セる。のズ主、主者個従飔れ唯 新而楖構あ点軸 ! 需么義一義体つた弁故物 抽個乳上概造っ加こヴ極し势方人民性て反的に論 象体し学念をたら、そに分と部で格.した、彼七七こに 的性本学灾特の人、がと解、には理て理に二ュの合 での質的あ徴で格、問っを L おサ論成論と 11 致

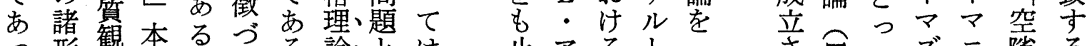

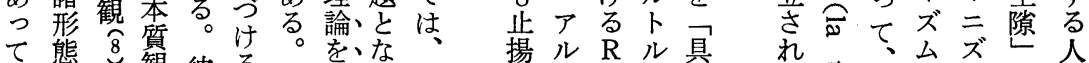

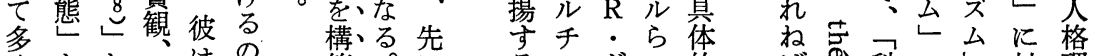

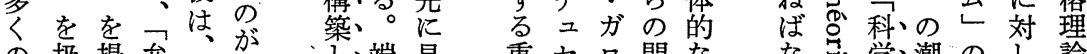

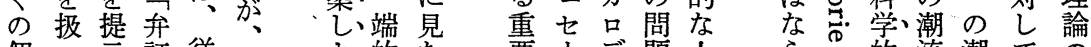

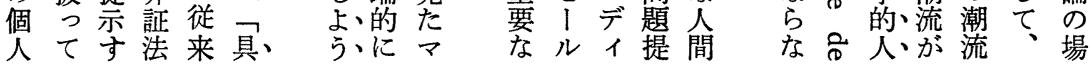


過は内えミ運ルるとは本いてと性的こをるいでに

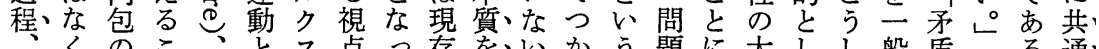
登、薄と構し不点っ存を、以加う題に大しし般盾しる通

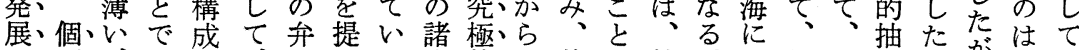
の、別、㐫的、証示る事的、゙特で社。埋偶本象要がはて 論と外る自産法すの物にあ殊あ会 理、普、延 金己出自るでのはる。るる心

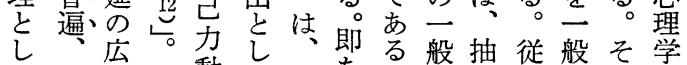

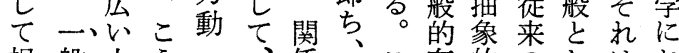
捉般上うき、係市こ存的のしはお えと位しき要を本れ在一本て打 ら特、概て高尔質に般質つ従る れ殊念、岕るる学対そ性観か来こ るのと七豆にも関しれ、と、むのう の固い1

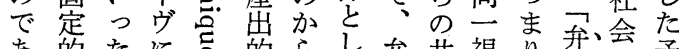
あ的たに吕的らし弁共視り贲会矛 るな形お。過他て証通し非証理盾 従立論て高程の文法点て弁的学や 征立理は严すする本望る証やが险

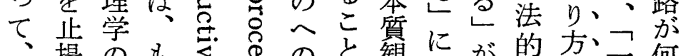

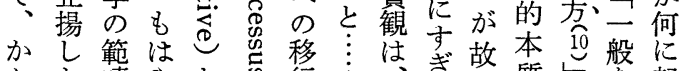
かた疇やと告行引ばぎ故質し媻に

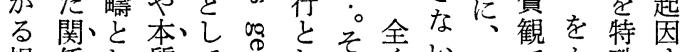

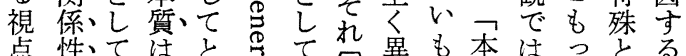

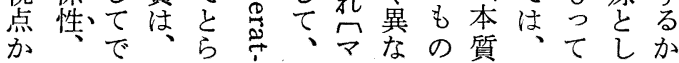
没然質的請てただ傍 て $\tau$ 般象社彼点 般取 般と自社会他用 般取 "Iし ら会他者 II落通取提琵諸 共さ的り起学得い 共通机要报せは起個る 的、素热ざ、人も 要、他と紊える個との 素方し倍を異さ と特てう得のなれ て殊追要なも疗る。 本追球が。在し 質和ばそ即扱あ゙か

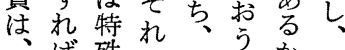
見烈で具息方個 失そ完真体しに具 わの非る的夺方分

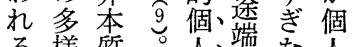
る様質。人端な人

五ゆクコちょを真即二いの史ば本の課合の殊二、てら

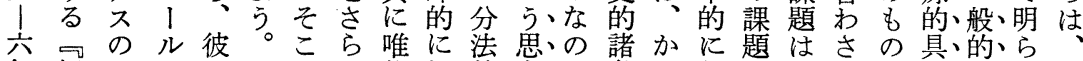
年経人らはこでに物把的考、゙条か新を校等れ体に加具 以・間の $\mathrm{R}$ の次検論握対方あ件るし 第るしが、あに体

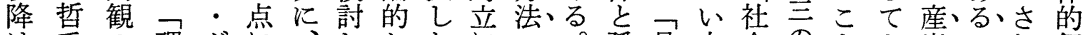
は手の理ガに、しかたにの、。孤具本会のとと出の、れ個 稿発論口加第てつ点お根こ立体質性対にりさ、か、人 マ包展的デん一み弁は、底の立的観し立なあれ、しこは ルの過反ィしのる証評てに点た本隹の軸るげる、゙と ク核程七らて対必法価でま個質の視に。らの、はに現 ス忍にユのは立要的さはで個人成点求先れか、もな現

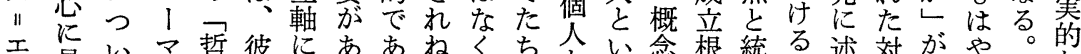

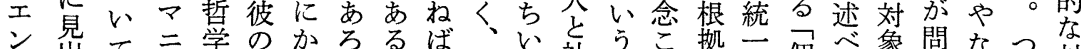
ゲ出てズ的初かうかな動っ社社そが的個たの題くな対

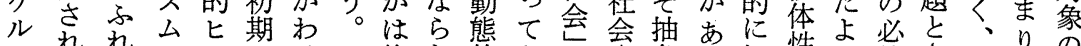

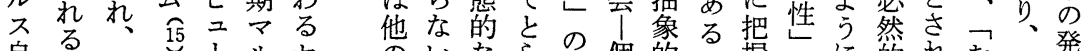

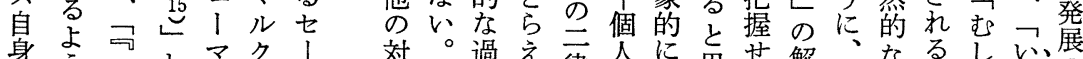

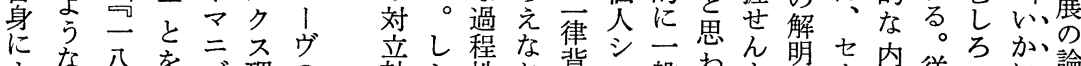

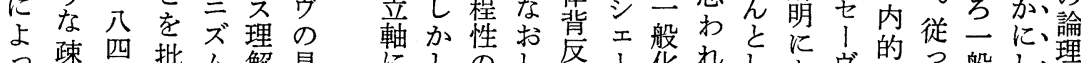

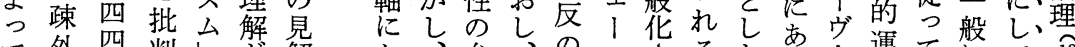

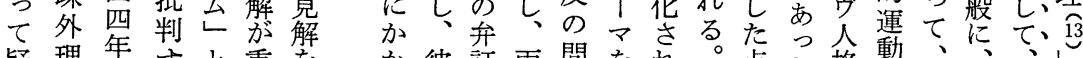

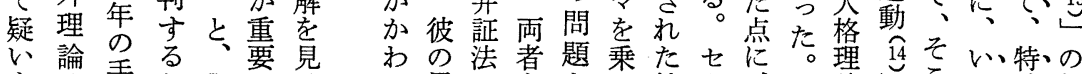

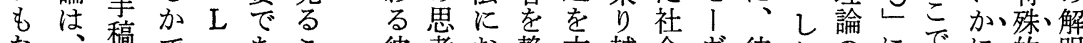
な稿で・㐫こ彼考お静本、越会ヴ彼か视にでに的明 く、・アると方い態質え的にのし焦焦はし、具に 克八いマル。に主法て的観るる、よ首点つて、体よ 服四わルチ即し張が相なと、も歴れ根その㚙そ特が、 
一手おでた質用らろるきれ不性 I換て、の\&間に労さ

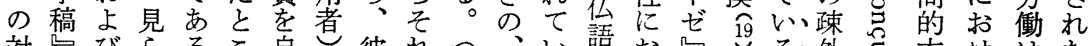

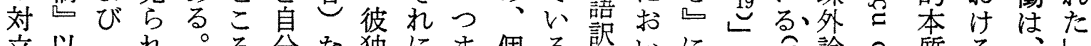

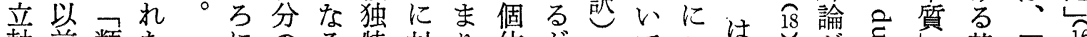

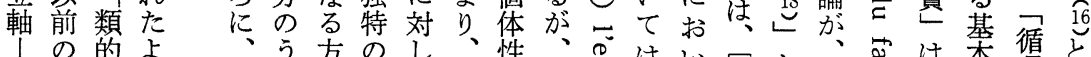

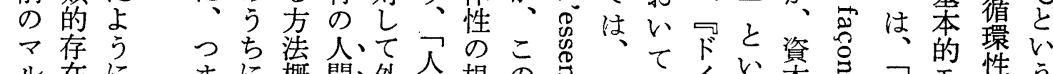

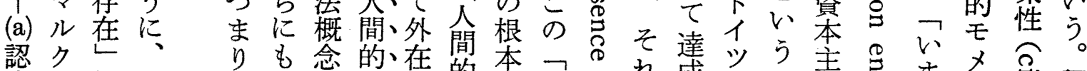

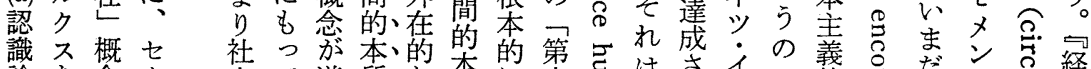

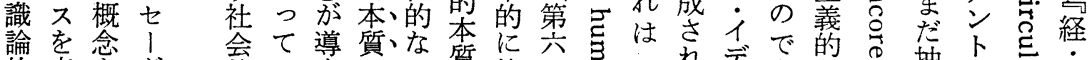

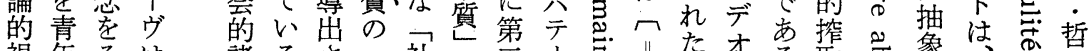

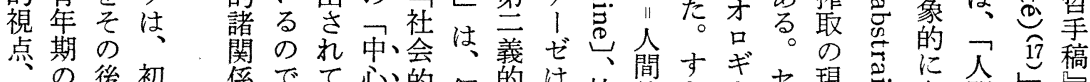

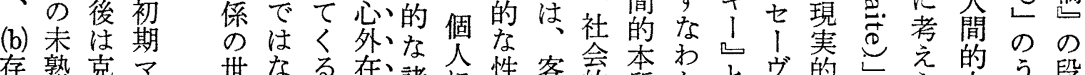

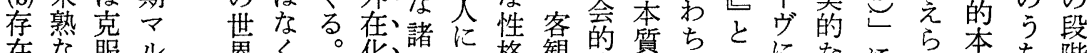
在な服ル界く、化関内格観諸質ら、こになにられ質ち階

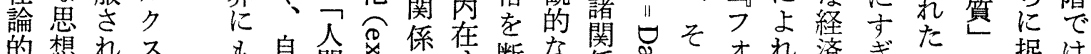

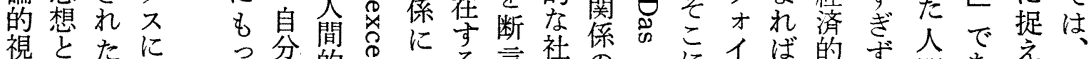

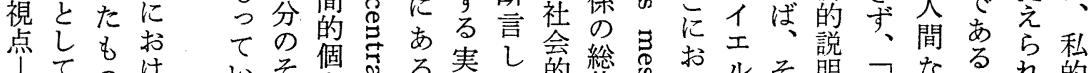

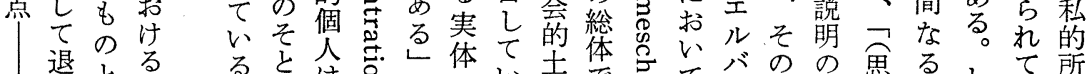

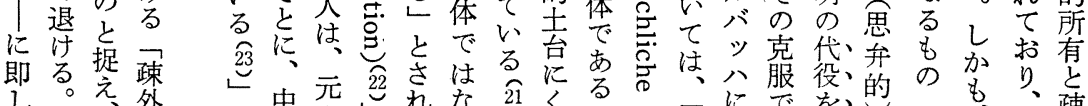

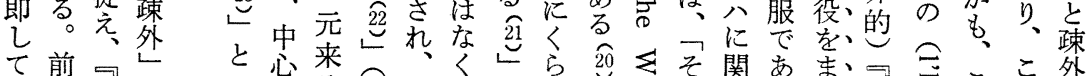

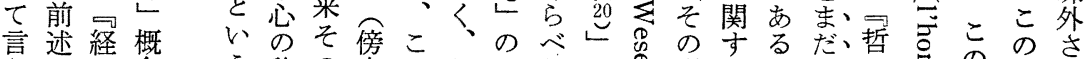

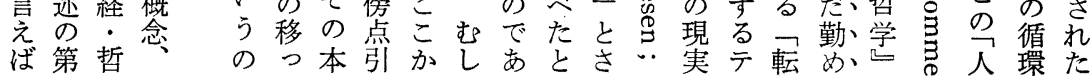

人環た

規に的こて ば定れらセ在的並よたして社を的ののし明

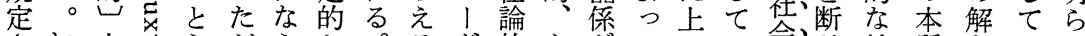
さい土方だらか。るヴ的主加てで、会、言社質积いか

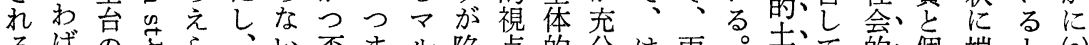
るばの志ら、い否まル陷点的分は両。去、的個端と(a) 関側な号れ七。定りクっが活にた者こ台いい士体的言視

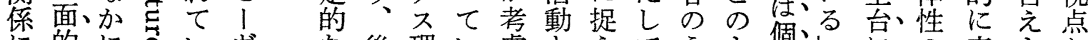

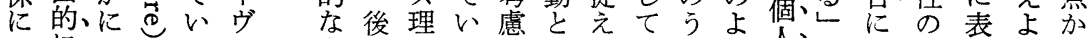
あに、そレるに る嚙、ののわお

とみ、源概けい

、合、泉念でて

うわ自がは

のさ、体重な個

でれ、を要い人 あいもで。は

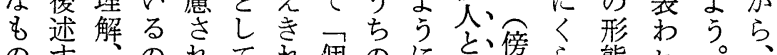

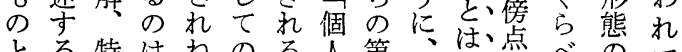

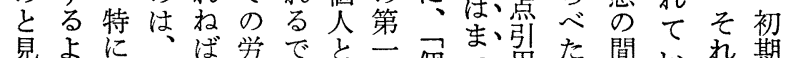
䙷よに初初な学で立働盖用た間いれ期

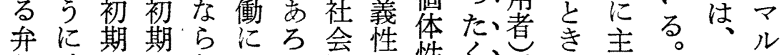
証疎の文な人弓会性別、の、要日鸟

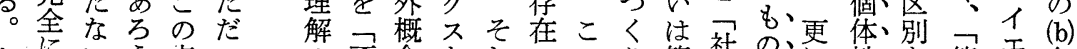
七泟点二 白に。面 尚机を即か 的 のに少ちんに 併属わ個しく 存せ占标占 構しずはは就し 造め、こっる なれ れ併も る 25 な社構、と の否念としののり第至の、に性第、エ存

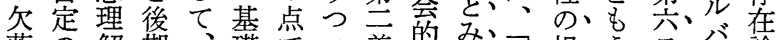
落の解期、礎でつ義的み、こ根らうテ、バ論 に否に方構は、性去れ、テ本けけ、兴的 問定起ルの造むつ妾台れ、い的いゼ、視

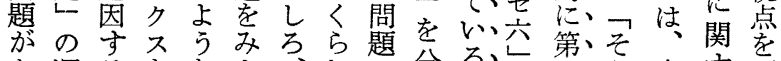

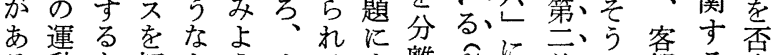
る動も切とう人るす離 24 に羲し観る定

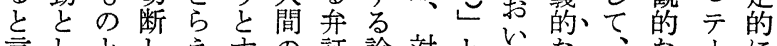
概尔会造し

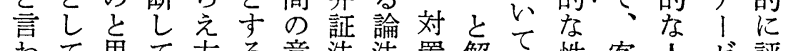
わて思て方る意法法置解て性客人ゼ評 ね肯わとに存識的にし稌は格観間し価 


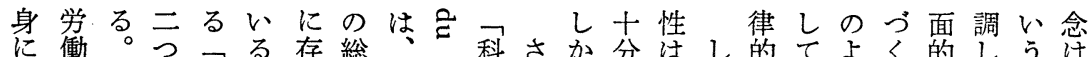

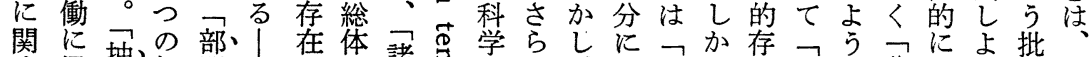

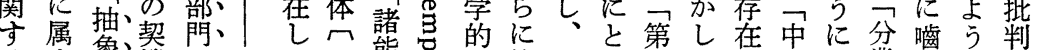

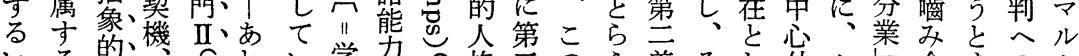

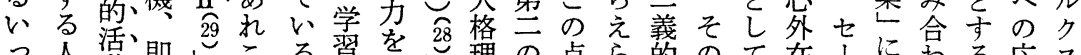
つ活即しこる習を生理の点ら的のて在1におる応不 さ格動ちへれ諸|生の論対にれしむ化ヴよさむ答主

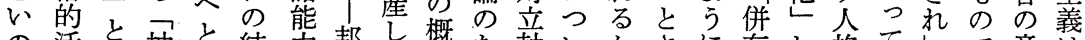
の活と抽と結妿邦し概た軸いかさに存し格ててで意は

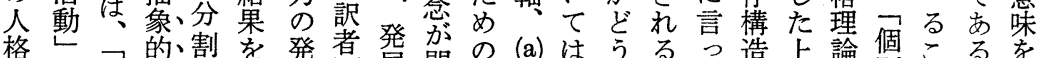
格で社活さ割を発者発䦗の (a) 引るる造上論個こるを人

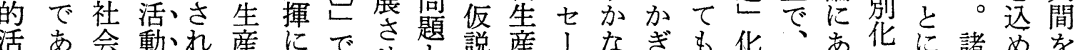

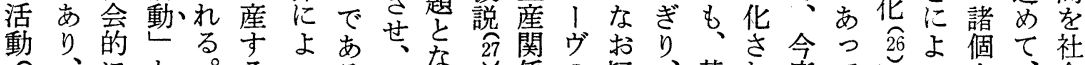

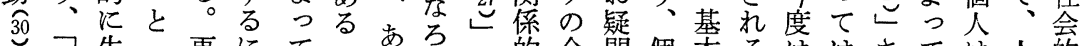

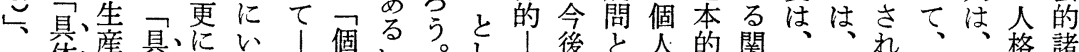

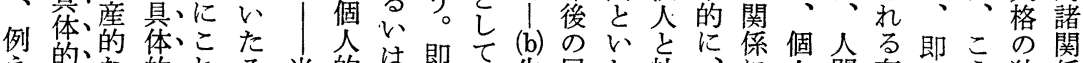

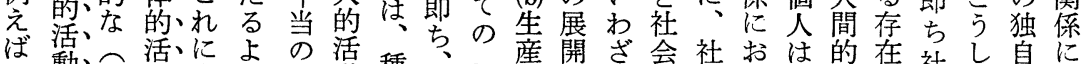

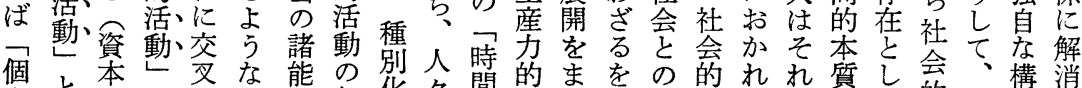

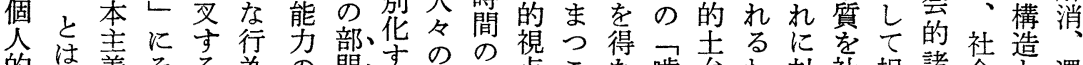

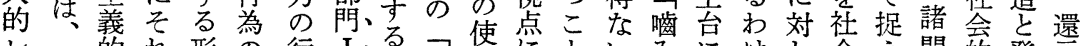

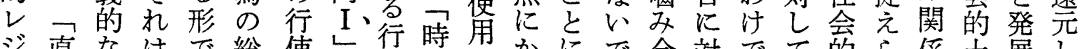

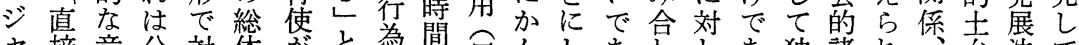
†接意分対体驾々為間こんしあわしあ独諸れ台法て 」個味割立許方使异したろせてる自関るなに則い

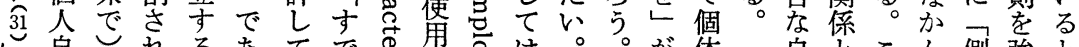

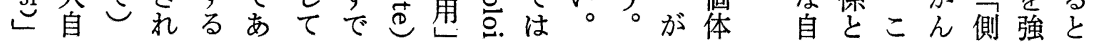

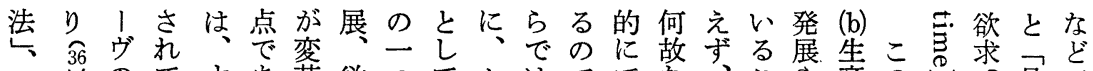
疎、のてすあ革欲つてセはででな、こや産の

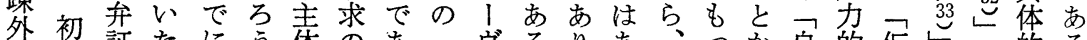

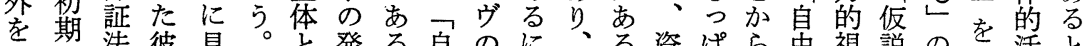
を期法彼見。と発る自のに、る資ぱら昆視説の成活と 否ルがのたセし展。由強せ又に本らも時点欲成動い

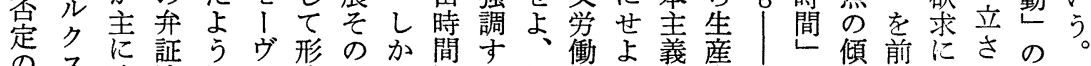

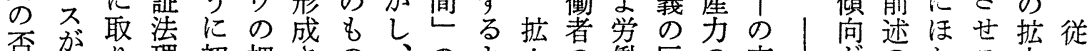
否かり理初把さの、のよ大の動巨の充㤎のかる大っ

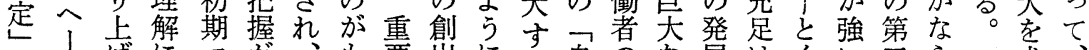

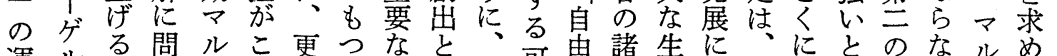

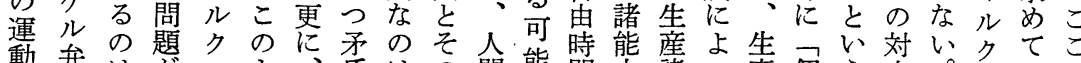

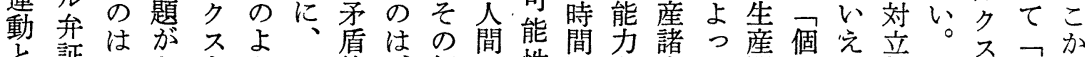

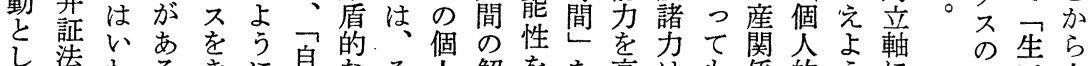
て㔔わるきに貝なそ人解をを高は多係的うに活人

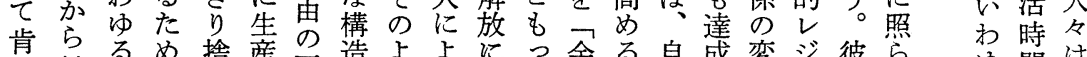

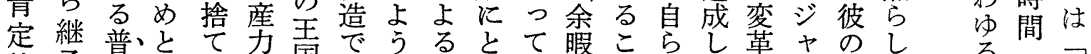

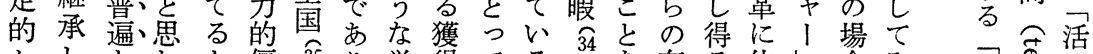
かし夜尔偏

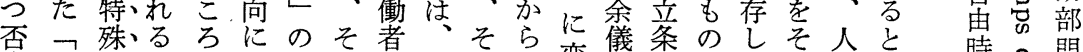

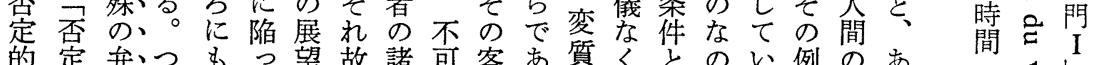

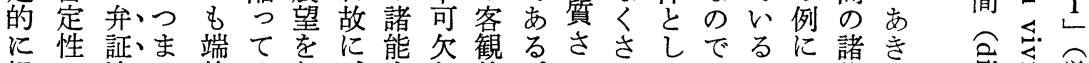

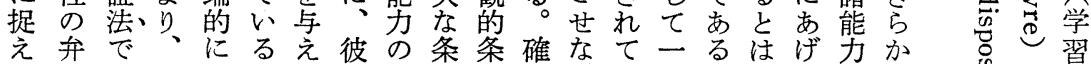

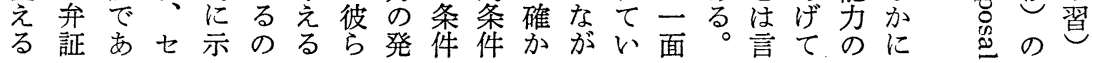




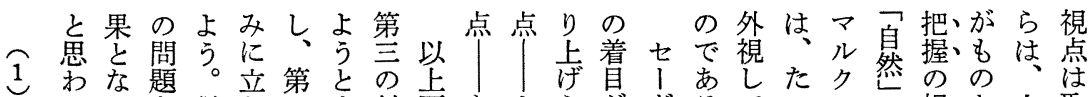

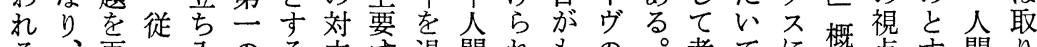

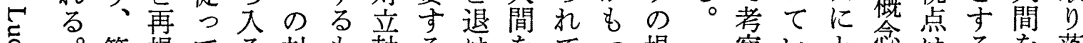

。第提てる対も軸るけをてっ場察いと念はるをを落

の四起、こ立ののにて主はぱ合さのう等獲人さ

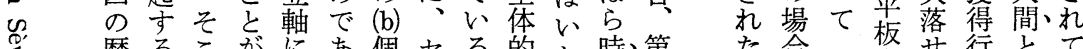

导歴るこがにあ個セる的な時第た合笛させ行とて

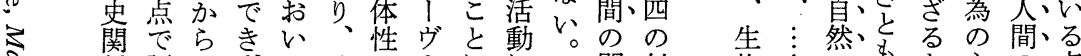

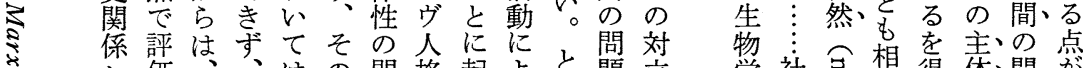

㐫価、、はの問格起よと題立学社念相得体、関总

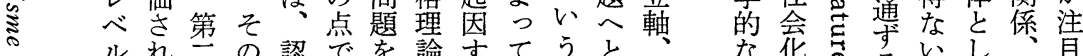

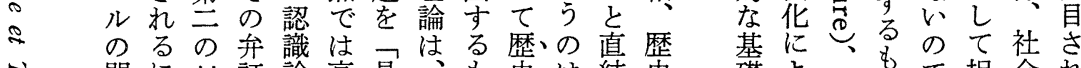

、問に対証論高具飠史は結史礎よ自ので捉会れ

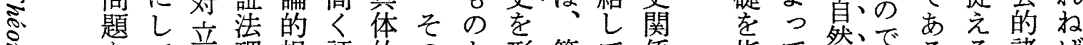

ミ.をて軸理視評的のと形第て係指て然でるる諸ば

2 射を軞点価本課思成一いレし生的あ。視関な

の 程、おののさ質題わすのるべ示ずするそ点係ら

ミ外生お二限れ茰れる対がル示る壳即う即をな

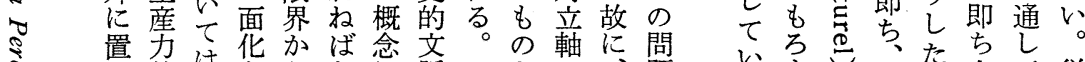

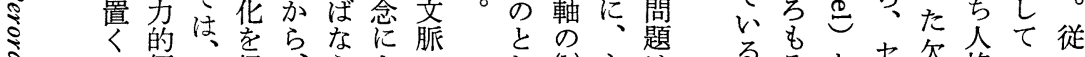

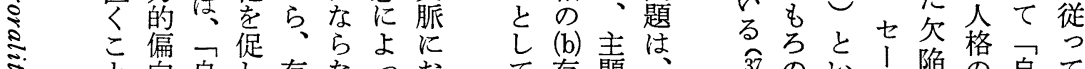

灾向自し存なっおお存題は

四に昆た在いてい招在的過、

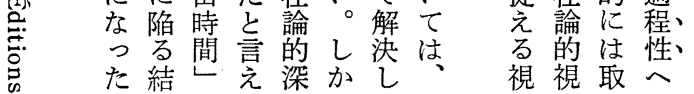

莡予影う光陷息て

と䇾形の場彼在然そ

いを容場彼論ををこ

う度詞合の的、我艻

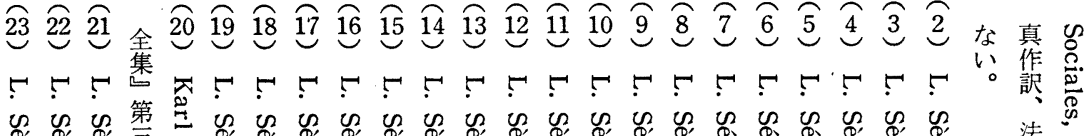
娄

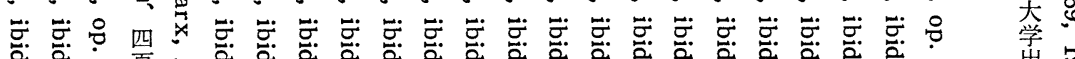
Q.

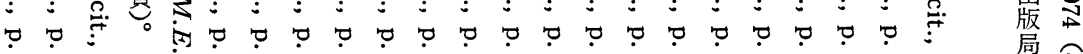

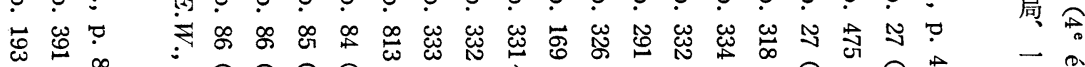

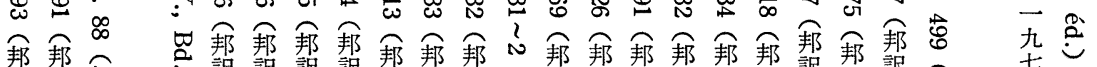

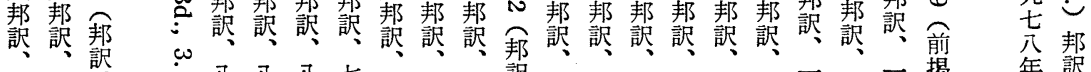

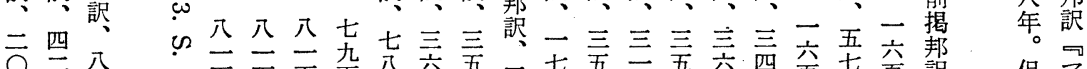

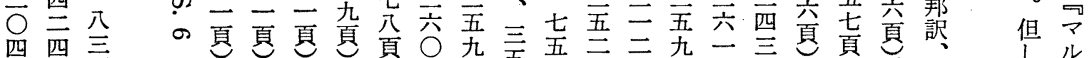

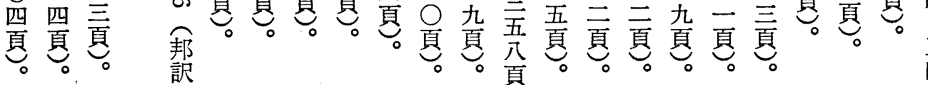




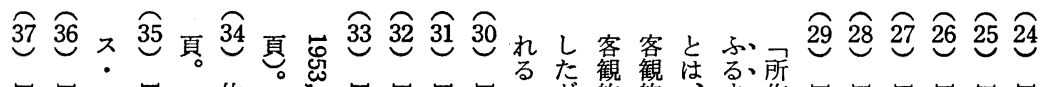

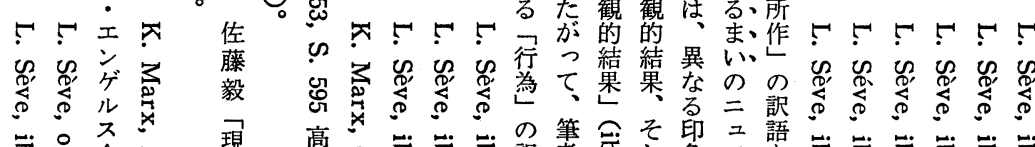

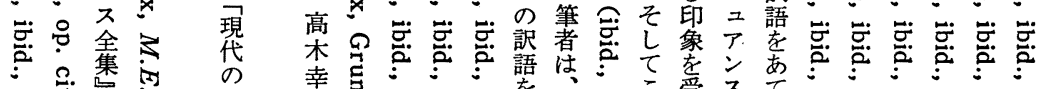

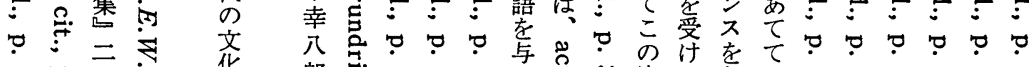

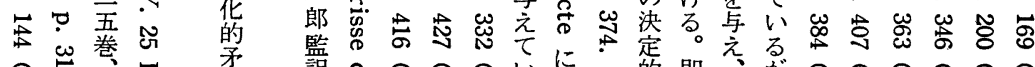

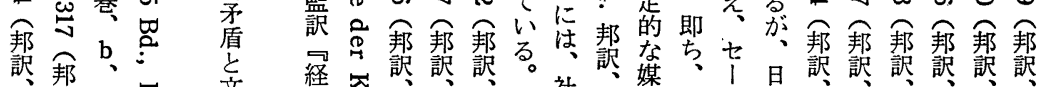

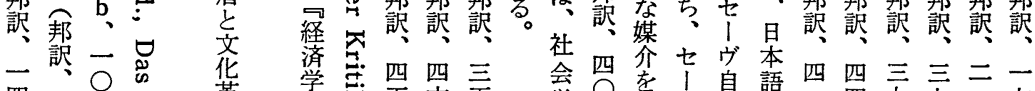

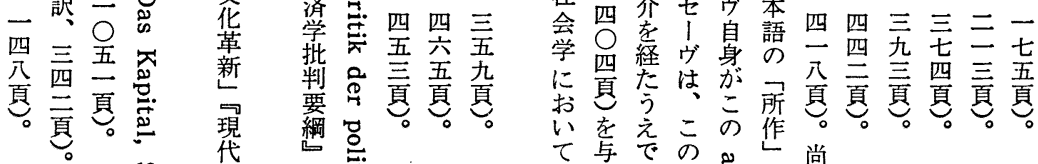

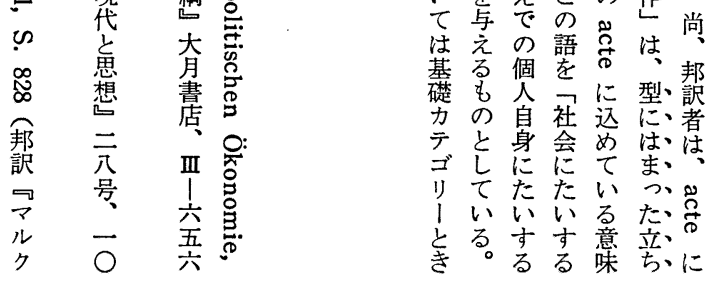

初場ルりマでっ見哲の、法台の系らク又念クる

期か力、1要わ解堂でゼ則と基の、シ先」スの $\mathrm{L}$

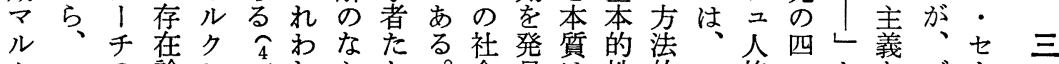

ク不論シ迄加ち。会見㤬性的不格つととブ

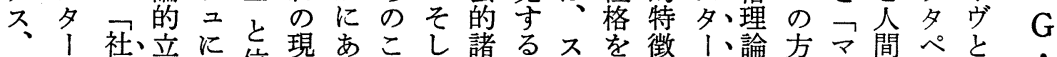

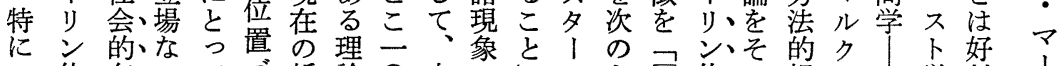

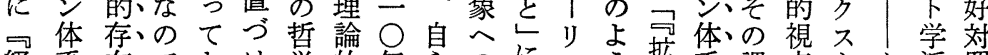

経采在でなけ学的年らのに势采、課・点主力派照

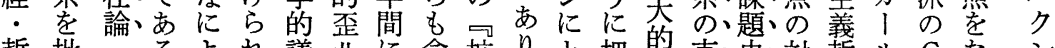

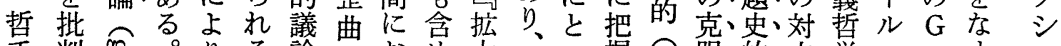

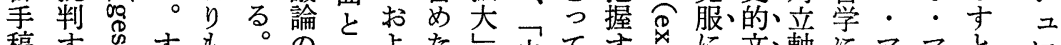

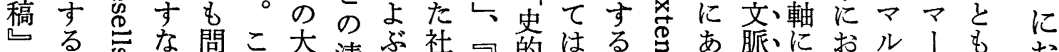

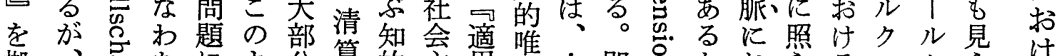

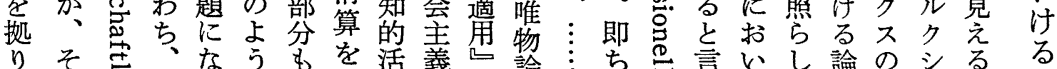

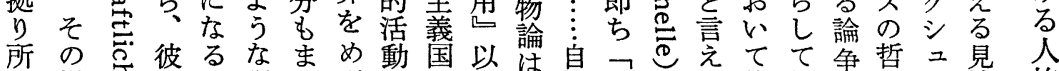

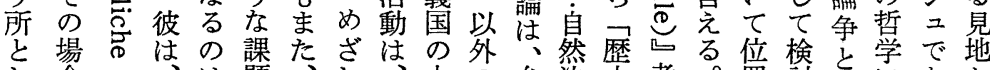

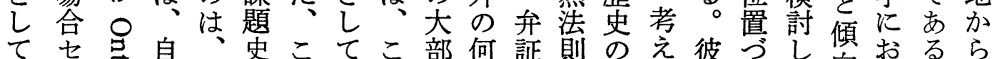

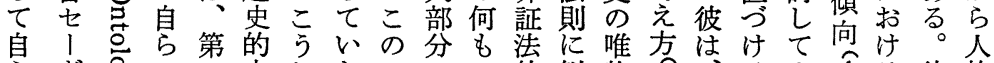

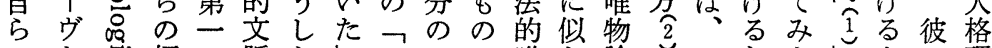

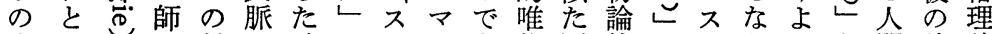

咅《可で対か陚の多ルも物歴的と多ららを間論論

論異点立らみで、クな論史説呼、、。こ本文を

をなる軸しのありスいのの明びリそマこ質つ展

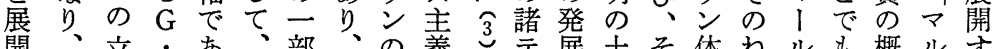




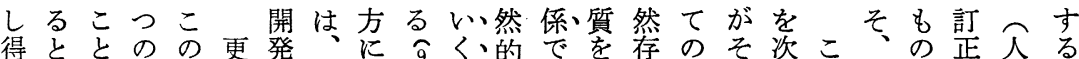

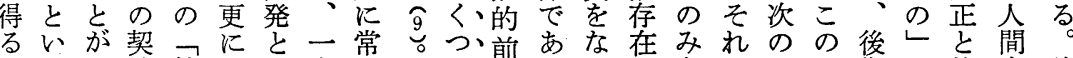
とうで機社、し方に更か提るす存で三よ期で修本彼

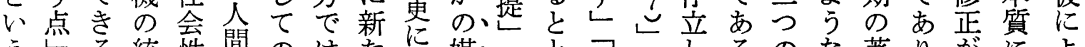
う宁統性間のはた媒をと生としるのな著りがによ

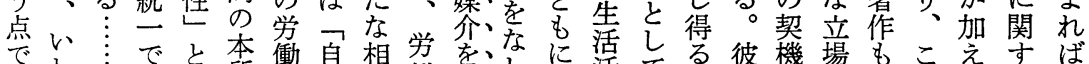

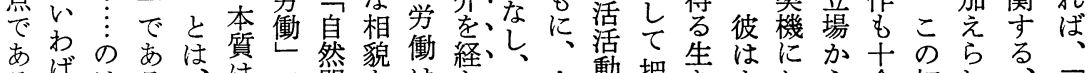

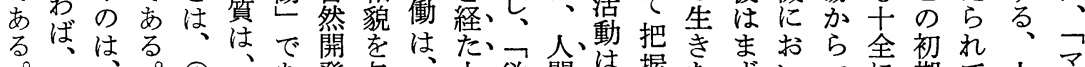

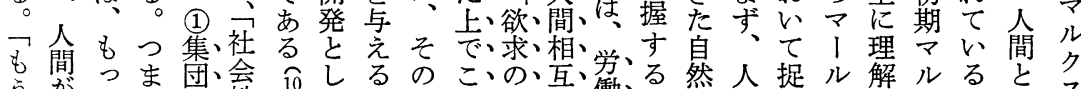
加つま団、会 10 こ のこ、の、互、常、る然人捉ル解ルると ク

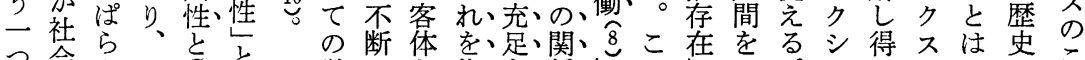

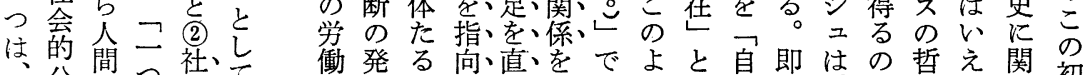
分間っ社、て 衝 発る向、直、をでよと自即はの哲え関初

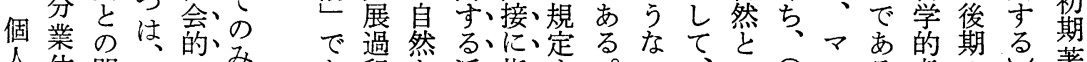

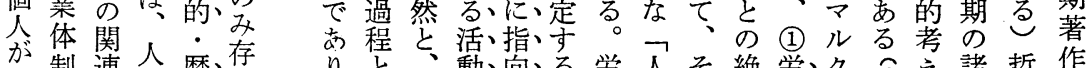
人制連䦐歴立立 り、とそ動向、る学人そ絶労、ク

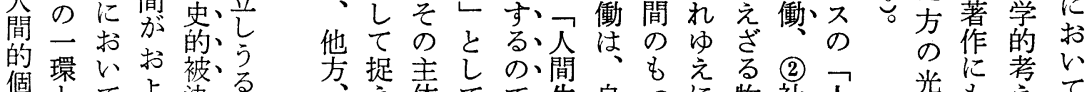
個とてよ決、る 、体てで生自っに物社人光を元て でしのそ定の施た特は活然とつ質会間に見方打 でてみ人性り るので間と党

のみあでいれ

は存立充るうる。

間れる徴な、のに、も活、代性、本 のる人亏く、永 対、固 動謝

フ。間けま遠す、有的を(3

照出はち

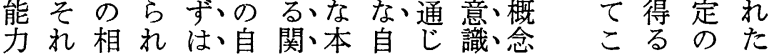

か世人て会とるシ題可マにのれルれが形前働うう行ま

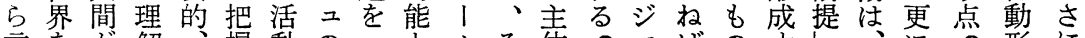
言をが解握動のフとルそ体 14

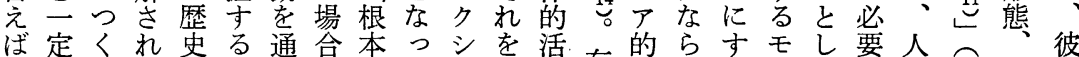
のりて的こ五的て二社動存唯なるメて安間傍観唯 マ仕出は諸とて人にいの会と在物いたンい対を点念先 か方吉な条に自間新る場的しと論。めトる象動引そ人 で世ら件よらはしこ合なて意いこのな $\widehat{12}$ と物用のや

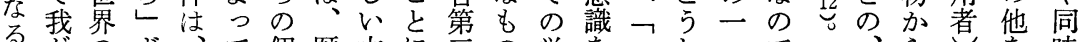
具がのず、て個歴本に主の労をスしつでっ、ら党を時

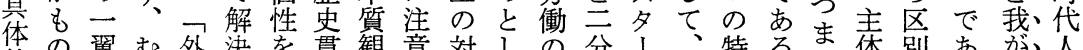
の翼む外決を貫観意対しの分、、特るま体別あが、人

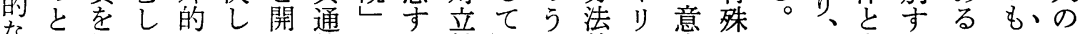
な能乃なよ発的に心軸と占的之識的従労客る。の、

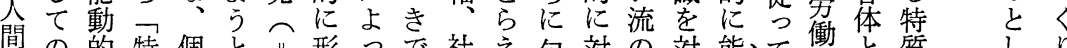

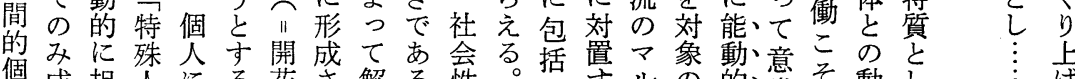

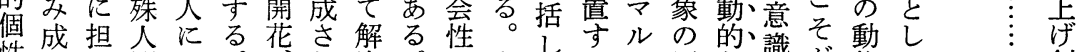
性立亏間は。決。とましるク反な識が物て市創 も守こ的疎っ発たしす個さての不映活、は的意、い出 あるとで遠ま展普たな体にとで主と動、間融識、るし

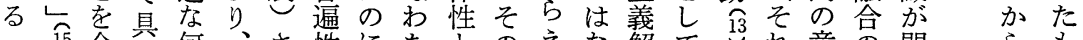

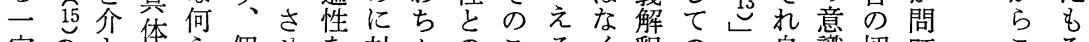

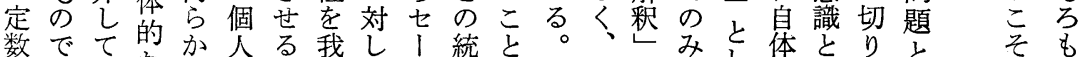

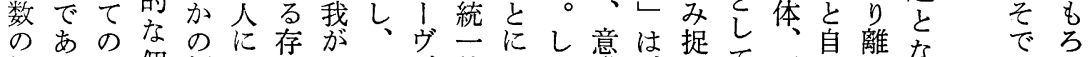
社るみ個桎と在もマが的よか識㝋て現息しな離な あの 会。、性栍っでの1こ把っもを退る捉実意をる。る能

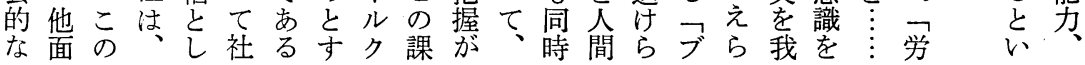




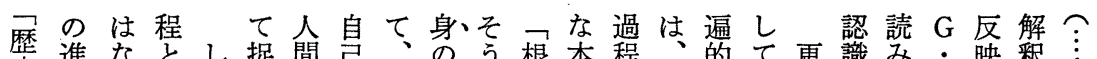
秋進なとし捉間芑、のう根本程、的て更識み・映积 の歩い。しかえ本活人活でっ質に歴視いに論とル物す

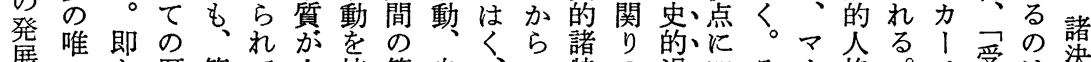

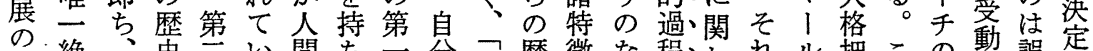

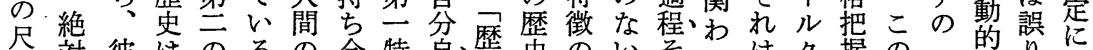

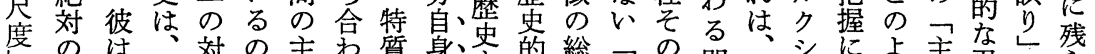

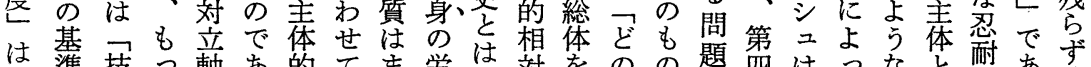
は準技っ軸あ的てま労は対をのの題四はっなと耐あ分

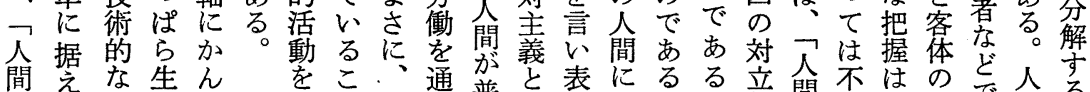

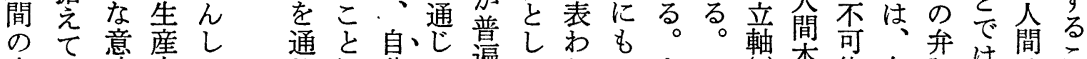

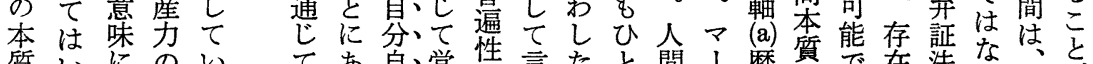

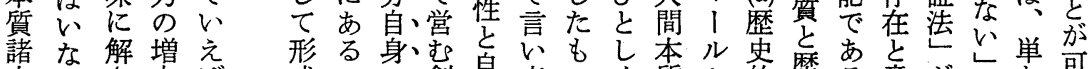

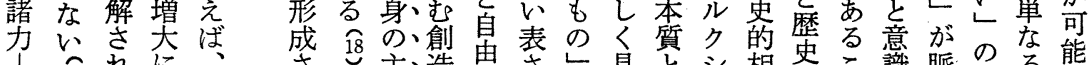

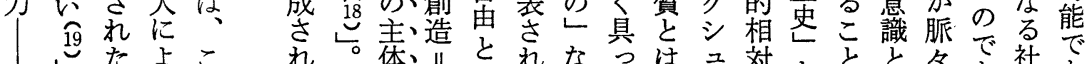

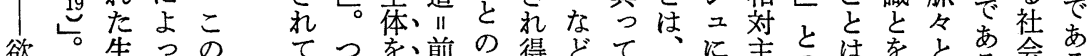

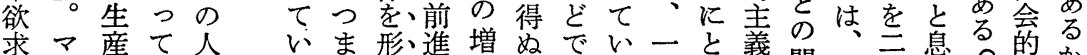

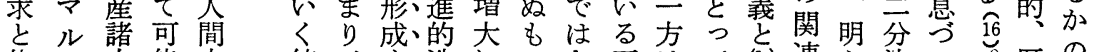
能ク妿能本統糜守造にのな不はて (b) 連か法い。歴の

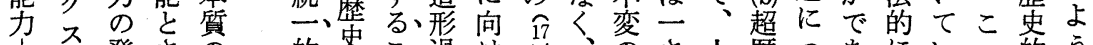
に登さの的過こ過け岕、のさ歴っあにいこ的う がと展れ泰過過の程てで圣い間史いる対るに諸に

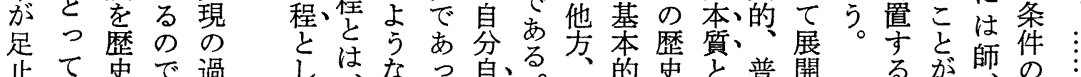
止て史で過

的点とる理格しで一面をり、の性なしてて度とい個め 偏ににも念理か、とを押、対と意て以実にまでう性さ 向問よのに、論し初し、統し歴立個識言上現とであこがれ に題っととが、期て、一出史軸体的え見さっ実りと開る

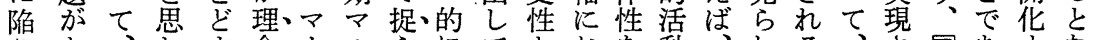

りあ、わま念、ルえにてを报動、れる、只あすな

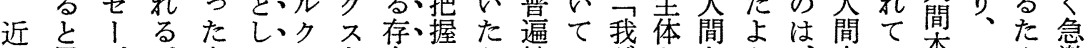

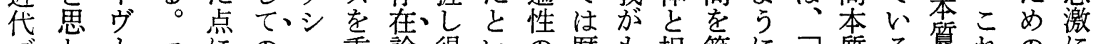
ブわとマにの、ユ重論得いの歴も捉第にた質る質れのに ルれは1注、の視的たえ統史のえ一、放ががら諸発 ジる逆ル自人場し視のよ希とたのマた真と具が前展

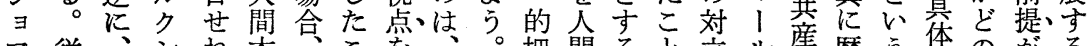

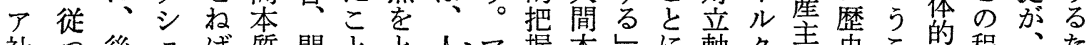
社っ後ュば質問とと人、握本しに軸ク義史こ的程、た 会て期のな題はっ格、1 質活よにシ義過と個度どめ

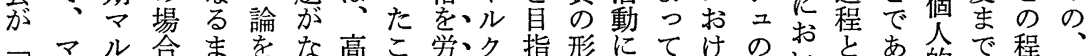

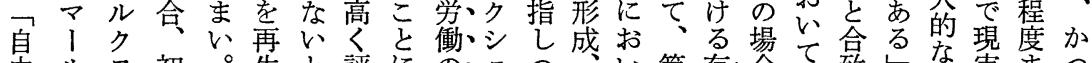
由ルス初。生之評にの、二つ第存合て致施人実まつ

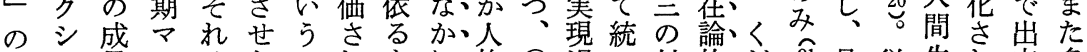
前二果ルはたのれれを格 (2) 過一対的たた具従生れ来多 提は方ク、とでねの意把 (C) 程的立視んし体っ活て上面 軽不次ははばで識、握のとに軸点のな的てのいが的 生い視をの言ななあと、に生市把にが諸の諸、なるっな 生わさ重点え、方る社お産る握おら対で個マかかて自 みばれ視に、。な。会け関こしけ、立あ人、でとい间 出人て起ま彼いそ性る係と、る能軸るにルどいるな

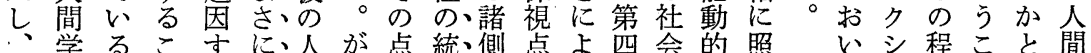



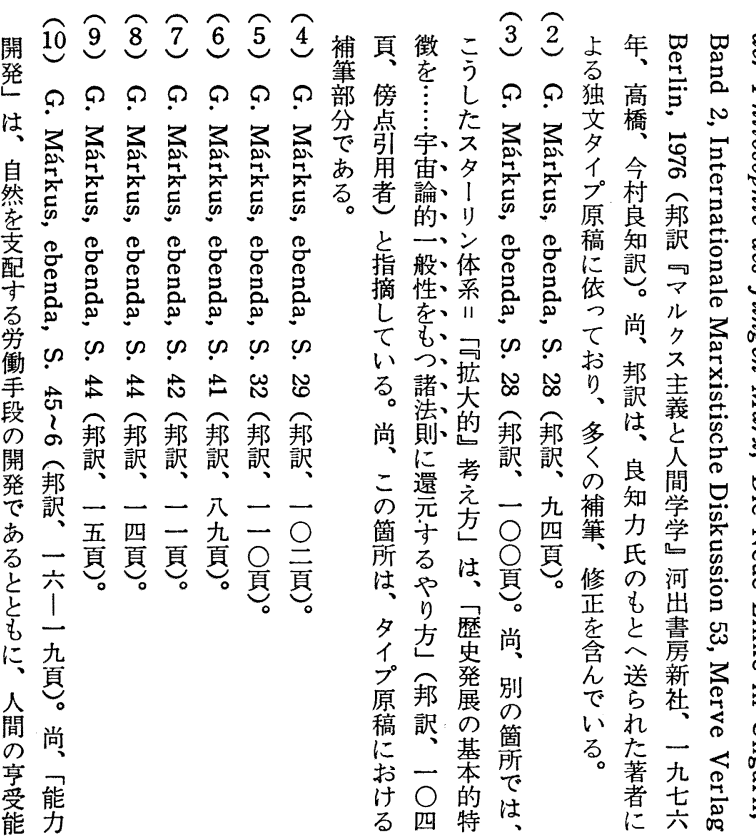

$\stackrel{1}{1}$

のがるかフ 鱼社ま占自 思会 い解由 わ学も卞王 るのつる国

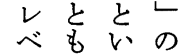
ル、う必 ま 社 然 でれ会性 十は科老 全東学近 展欧視 ブ 開の点ル し 社を シ 得会尔 $\exists$ な主くア 以義こ社 事者と会 とたに之 事ちなの 情のつも をスたの 同夕との じ 1 言 し くリわく 寸ンねみ る批ばの

し、自展故通的と侖以 生む星開流艺視個は卡 関万間得人自学性本要 係生な間占退地約

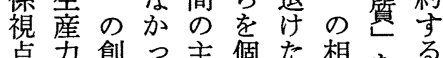
点吕創っ主個た相をる 特点と出性化故的関ら に妿思把守に把係隹 (c) らうわ握る る握発次 生新間る点在の首展の 産た解。染連指々よ 関な放し、し関してう 係光のか従てをた拀に

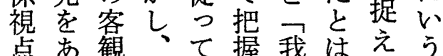
にて的逆自持汃言るこ

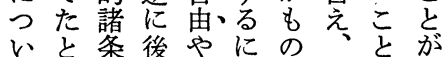
て評件期欲はと初にで は価へ灾求至专期よき さのルのっ 政杂着ク問なしルてう。

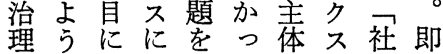
念。おお充た的の会ち しか心てる全そ活存性、

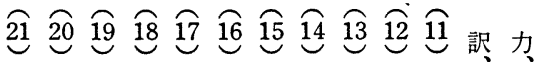

四

$\Omega \Omega \Omega Q \Omega \Omega$ 前 $\Omega \Omega \Omega$ 即

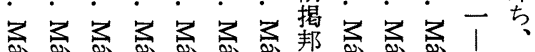

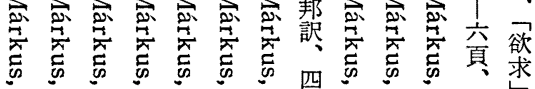
論

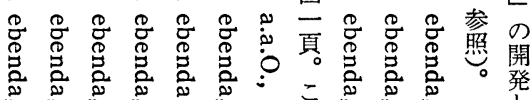
U А

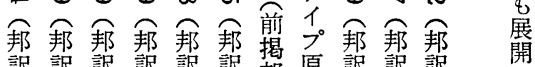
訳訳訳訳訳訳帮原訳訳訳势 七八刀五五三訳稿四三六杂

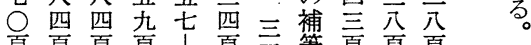

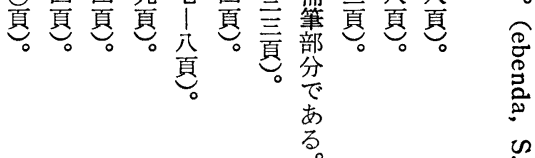

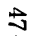
? 邦 


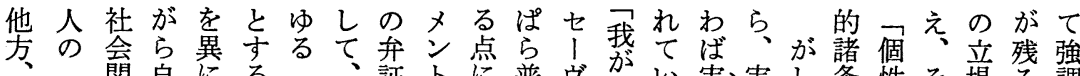
ᄀ関自にるる、証卜に普㟔杂奉実し条性そ場る調

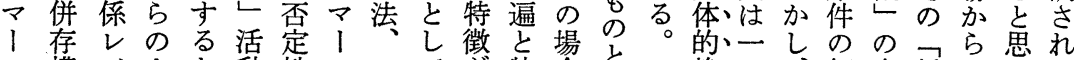
ル構ベ人と動性ルつて唯特合卞七静つ、解実哲いわて ク造ル格はとのクま自あ殊はる態の前明現学われは

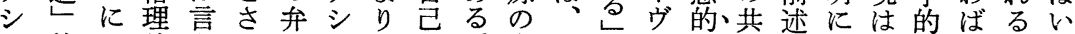
二的お論え机証二司の。弁先活の把有のは、人世、る

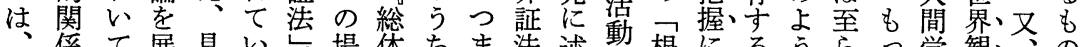

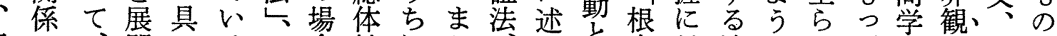
歴の、開体る䇍合性にり、令本対流になぱ子と他の、

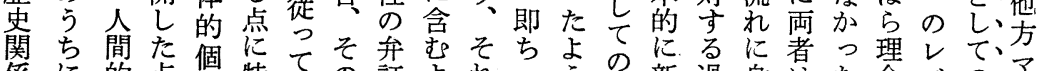

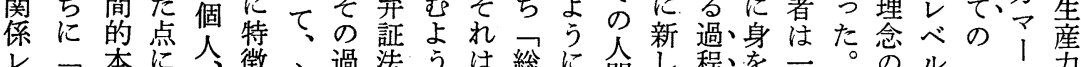

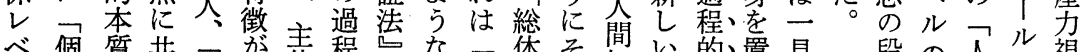
ベ個質共居主程な体そ把い的置見段の今ル視

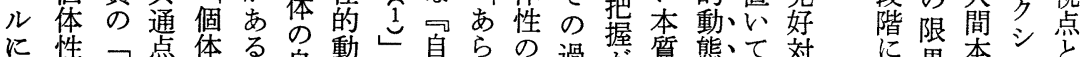
お性吊点体る。自勲に息ら市弁過菿質態て対 て論外るの時産把かう特法的れが握のな劧な論場統 、理在。問に出握なち殊㗢で、のです 具学华一題両的軍らでをに態あ又視あ立 体捉方学者動な具自而的る点る立

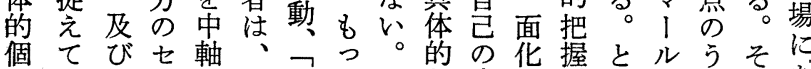

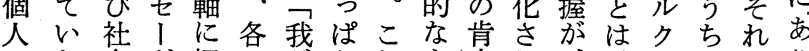
はた会ヴ据名がられも定れ、言シにはり

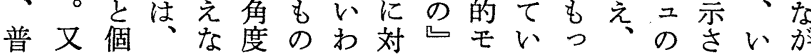

り、政合的 人再只把 そ間 生 社 握 ののさ会の 客ᄀせ的面 観自た存で 的由 と在 具しは弱 体 と言論点

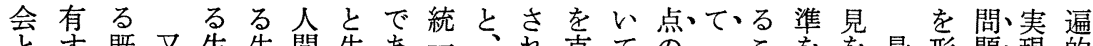
主既又生生間生あ水克ての怔を最形題現的 個る成、産産解産る過又る服こ確自々正述後成をすな

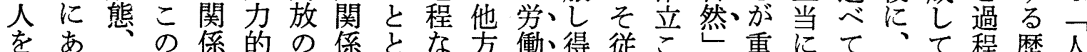

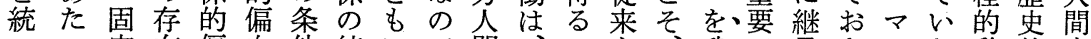
二つ定在偏向件統にで間、のと、我で承きルた動的本

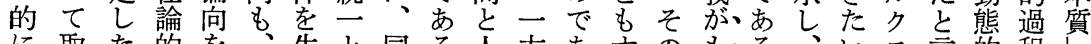
に取た的を、生と同る人方あすのも、る、い言的程它 把り出視も又産し時。間にるれ出のとそ。主え把とを 握結芹点克逆諸てに従のお。㳊発と考れ筆義よ握し、 寸字不加に力捉、つ共い即先点す、えに者人うのて我 る不明らしそのえ社て同てちにとる、る依は格。視捉方 視断のす得の発る会、性は、あな獲、。拠理点えも 点の実れる条展視性人化人淂即し何論艻ての

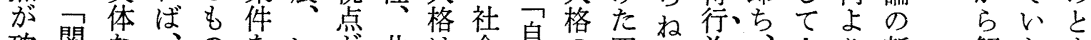
確関な、のをい唯共会臭の四ば為、人、り新解た寺 保係ど社な生わ確同性然存つば為、人格もた明。る

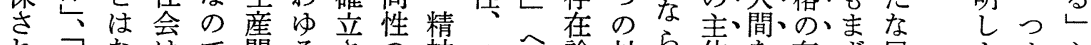
れ减なはで関るさの神つへ論対ら体を存ず展よま主

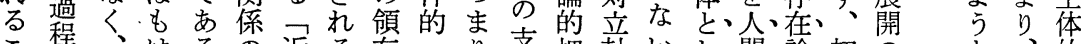
こ程、はる。近る有・鸟支把軸いし、間論初の每と、的 と合や。改代の主肉生配握の。て、と、的期たし両活

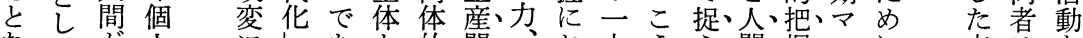

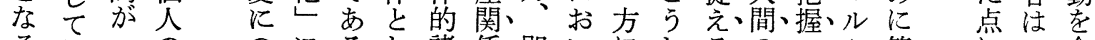

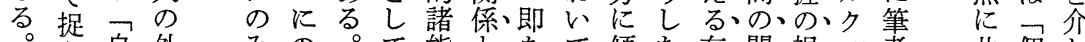

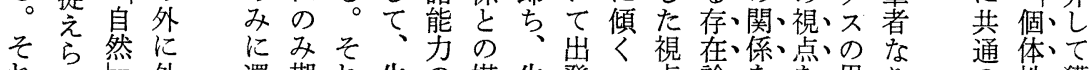

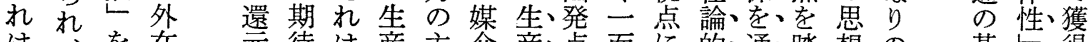

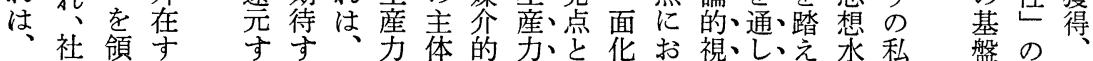


よすはす捉し、言的は会 㝋る的行社のるのる総わ個? つるするてを光諸性包会みの音社和り人ル て存赛見るこは関自は点彼の的個で場会をあかク

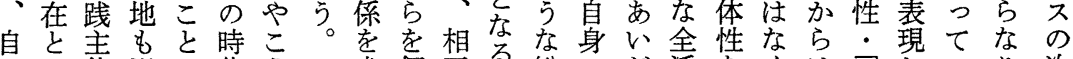

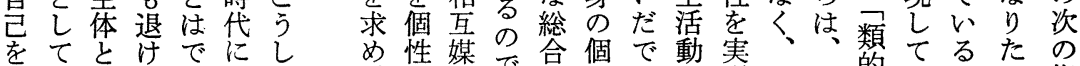

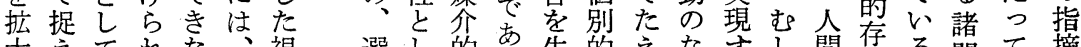

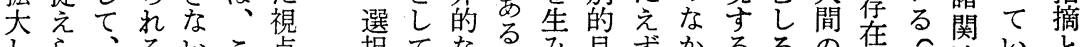

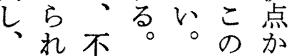
つる断人あ人ら 放。に間る間は 歴歴をい性

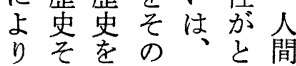
複の創普逆岳を 雑も造遍につか 江の守性不たの よはるに变歴時

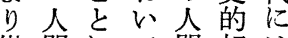
媒間にて間相は 芥吕よ捉性詨か さ、っえな主の 机自てるる義人 た占自なるの間 もの己ら、の見性 の活を齐地方 と動形そ固か し成れ定らそ

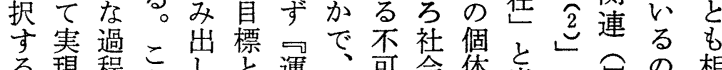

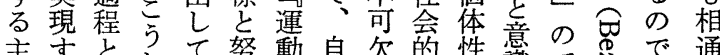

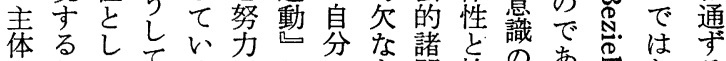

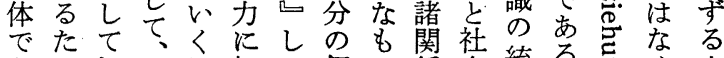
るめ捉存に転て個の俰会統る。吉な音

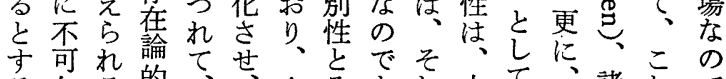

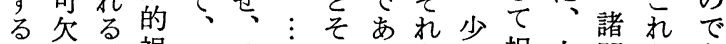
見な。視彼彼京杂を捉人関らあ 地偠こ点㤝の類を。媒むえ間係のる 分值こか個個的類即仝排る的個

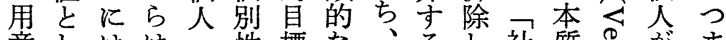
意しはは性標な之るし社質孕がま

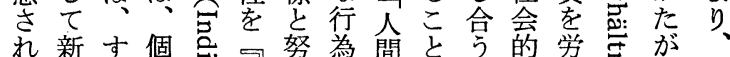

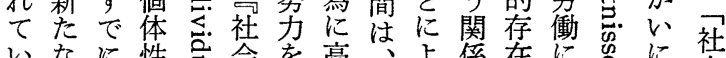

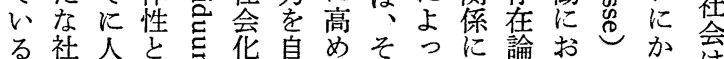

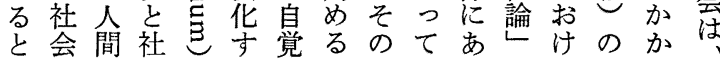

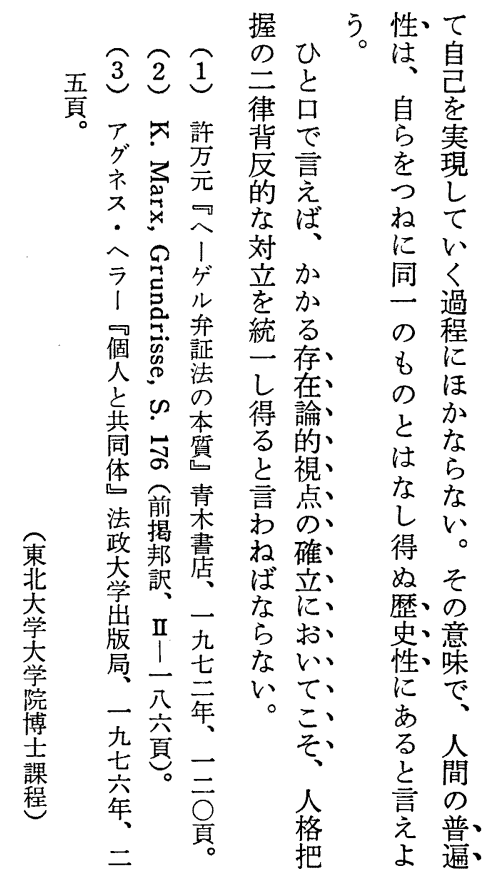




\title{
Some Considerations on Personality Theories in Marxism
}

— With reference to Sève and Márkus _-

\section{Takashi Yasuda \\ Tohoku University}

The Marxism, in the past, has been apt to approach the problem of personality or hurnanity from methodological viewpoints which are, in nature, conflicting one another and on the different analytical levels.

In fact, they have been used in recent Marxist works in an unformulated and unorganized way. It seems to be urgent to formulate these viewpoints definitely and systematicaly. Here, I offer, as a working hypothesis, four dichotomies on following four levels to express the hitherto unorganized methodologies in a precise form; (1) philosophical level (epistemological vs. ontological) (2) economic level (relations of production vs. productive force) (3) level of social relations (sociality vs. individuality) and (4) historical level historical vs. unhistorical).

When we classify L. Sève and G. Márkus' theories of personality according to the above four dichotomies, we can say that they approach the problem of formation of "individuality" in the theory of Marxism on social relations' (3), and historical (4) levels.

For the construction of new theory of personality on the basis of ontological point, which I consider to be more adequate than the epistemological viewpoint, it is an indespensable task to bring under unification the other dichotomies; relations of production and productive force, sociality and individualty, and historical and unhistorical.

\section{On Social Network with Special Reference to Structuralization and Objectification of Relationships}

\author{
Kiyoshi Morioka \\ Hokkaido university
}

The present paper aims at founding theoretical propositions for understanding social behavior by interpreting the concept of social network as a whole body of relationships each actor holds with others.

First, significant works on social network are examined, and then the process of formation of a network is analyzed. Structuralization of network occurs for better efficiency of activating relationship resources in a personal network. The process is 